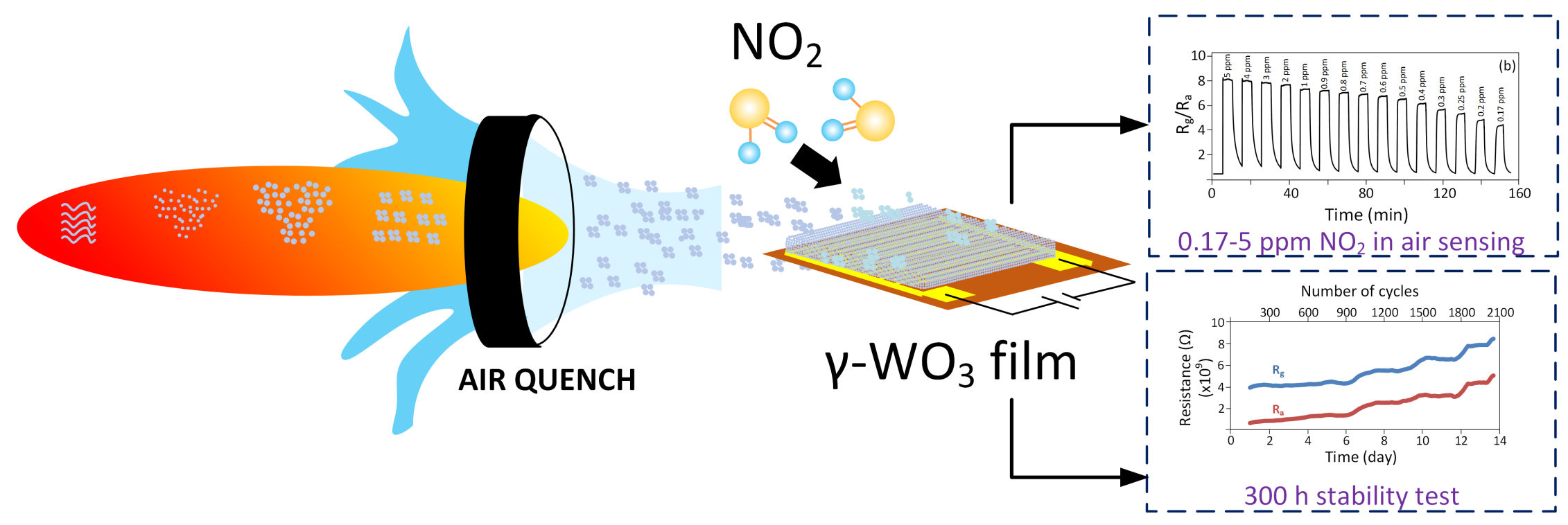




\title{
Ultra-low $\mathrm{NO}_{2}$ detection by gamma $\mathrm{WO}_{3}$ synthesized by Reactive Spray Deposition Technology
}

Rishabh Jain ${ }^{a, c, d,{ }^{*}, \text { Yu Lei }}{ }^{b}$, Radenka Maric ${ }^{a, b, c}$

a. Department of Materials Science and Engineering, University of Connecticut, 97 North Eagleville Road, Unit 3136, Storrs, CT 06269.

b. Department of Chemical and Biomolecular Engineering, University of Connecticut, 191 Auditorium Road, Unit 3222, Storrs, CT 06269.

c. Center for Clean Energy Engineering, University of Connecticut, 44 Weaver Road, Unit 5233, Storrs, CT 06269.

d. Institute of Materials Science, University of Connecticut, 97 North Eagleville Road, Unit 3136, Storrs, CT 06269.

*Corresponding author at: University of Connecticut, Department of Materials Science and Engineering and Center for Clean Energy Engineering, 44 Weaver Road, Storrs, CT 06269-5233, USA. Tel.: +1-860-465-6454; Fax: +1-860-486-8378; E-mail addresses: rishabh.jain@uconn.edu; rishabh.rjain@gmail.com

\begin{abstract}
:
A porous tungsten oxide $\left(\mathrm{WO}_{3}\right) \mathrm{NO}_{2}$ sensor was developed by a one-step flame based process called Reactive Spray Deposition Technology (RSDT). This nano-crystalline $\mathrm{WO}_{3}$ film was deposited directly on gold interdigitated electrodes. The sensing characteristics of this $\mathrm{NO}_{2}$ sensor was measured at the parts per million (ppm) level, $\left(0.17-5 \mathrm{ppm}\right.$ in air) at $300^{\circ} \mathrm{C}$. The sensors
\end{abstract}


showed a relatively fast response time $(\sim 7 \mathrm{~s})$ and recovery time $(\sim 5 \mathrm{~min})$, respectively. The stability of the sensor was evaluated for $300 \mathrm{~h}$ in $0.5 \mathrm{ppm} \mathrm{NO}$ at $300^{\circ} \mathrm{C}$ in $(2000$ response-recovery cycles). The sensor was stable up to 6 days $(\sim 150 \mathrm{~h})$ of continuous operation and degraded between 150 to $300 \mathrm{~h}$. The morphology and surface properties of the $\mathrm{WO}_{3}$ film were investigated with XRD, Raman spectroscopy, BET, SEM, TEM, and HRTEM.

Keywords: Gas sensor; Combustion; $\mathrm{NO}_{2}$ sensing; Flame spray pyrolysis; Tungsten oxide nanoparticles; Reactive Spray Deposition Technology

\section{Abbreviations:}

RSDT: Reactive Spray Deposition Technology

COPD: Chronic Obstructive Pulmonary Disease

SIDS: Sudden Infant Death Syndrome

OSHA: Occupational Safety and Health Administration

DOAS: differential optical absorption spectroscopy

CRDS: cavity ring down spectroscopy

REMPI: resonance enhanced multi photon ionization

YSZ: yttria stabilized zirconia

NASICON: natrium superionic conductor

PECVD: plasma-enhance chemical vapor deposition

PEL: permissible exposure limit 
THF: tetrahydrofuran

ICDD: International Centre for Diffraction Data

\section{Introduction:}

$\mathrm{NO}_{\mathrm{x}}\left(\mathrm{NO}_{2}, \mathrm{NO}\right)$ is a toxic air pollutant which is produced as a byproduct of gasoline combustion in an internal combustion engine [1]. Exposure to unsafe levels of $\mathrm{NO}_{2}(>10 \mathrm{ppm})$ causes irritation in eyes, nose and throat, while higher exposure $(>25 \mathrm{ppm})$ can cause severe reactions for people with underlying pulmonary diseases like Chronic Obstructive Pulmonary Disease (COPD) or asthma. $\mathrm{NO}_{2}$ reacts with water droplets in the trachea and lungs and forms droplets of nitric acid. These tiny droplets of nitric acid penetrate deeply into the lungs and causes various respiratory diseases. $\mathrm{NO}_{2}$ exposure has also being associated with Sudden Infant Death Syndrome (SIDS) [2]. A detailed report of the actual accidental release of $\mathrm{NO}_{2}$ and its subsequent health effect on the population is provided by Bauer et al [3]. The United States Occupational Safety and Health Administration (OSHA) has set a 5 ppm workplace permissible exposure limit for $\mathrm{NO}_{2}$, time averaged over an $8 \mathrm{~h}$ work shift. $\mathrm{NO}_{2}$ also leads to the formation of ozone which is hazardous to both aquatic and terrestrial ecosystems. Current methods of quantification of $\mathrm{NO}_{2}$ in the air includes gas chromatography equipped with mass spectroscopy (GC-MS) [4], chemiluminescence [5], differential optical absorption spectroscopy (DOAS) [6], laser induced fluorescence (LIF) [7], cavity ring down spectroscopy (CRDS) [8] and resonance enhanced multi photon ionization (REMPI) [9]. However, these analyses can be very expensive, requiring trained experts, and having complex, bulky and non-portable instrumentation. Metaloxide semiconductor based gas sensors could be an effective solution to the underlying limitations faced by currently used methods for measuring $\mathrm{NO}_{2}$. Metal oxide materials, such as yttria stabilized zirconia (YSZ) [10], natrium superionic conductor (NASICON) [11], $\operatorname{In}_{2} \mathrm{O}_{3}$ [12], and 
$\mathrm{WO}_{3}$ [13], have been used for $\mathrm{NO}_{2}$ gas sensing. Among metal oxides, $\mathrm{WO}_{3}$ is considered to be a good candidate for low concentration $\mathrm{NO}_{2}$ sensing.

$\mathrm{WO}_{3}$ is an n-type semiconductor with a band gap of $2.75 \mathrm{eV}$ which is known to exist in multiple polymorphs such as tetragonal $(\alpha)$ [14], orthorhombic $(\beta)$ [15], monoclinic ( $\varepsilon$ and $\gamma)$ [16], and triclinic $(\delta)$ [17]. Each of these forms exhibits different electrical, optical and magnetic behaviors which are favorable for particular applications. Gas sensing property of $\mathrm{WO}_{3}$ was discovered for the first time by Shaver, in 1967 when he observed a change in conductivity of $\mathrm{WO}_{3}$ thin film in presence of low concentration of $\mathrm{H}_{2}$. Since then n-type $\mathrm{WO}_{3}$ has been extensively used for sensing $\mathrm{H}_{2}$ [18], $\mathrm{H}_{2} \mathrm{~S}$ [19], $\mathrm{NO}_{\mathrm{x}}[13,20], \mathrm{NH}_{3}$ [21], $\mathrm{O}_{3}$ [22], $\mathrm{CO}$ [23], and acetone [24-25].

The essential components of a gas sensing device are: a metal-oxide sensing layer deposited on gold or platinum interdigitated electrodes which are attached to, an alumina or silicon substrate with a heater and a temperature probe to increase and control the temperature of the sensing layer. $\mathrm{WO}_{3}$ film deposited interdigitated electrodes possesses both receptor and transducer functions, where the reaction of the $\mathrm{NO}_{2}$ species takes place on the $\mathrm{WO}_{3}$ film (receptor function) and the adsorbed $\mathrm{NO}_{2}$ changes the resistance (transducer function) of the sensing film. This change in resistance can be correlated with the concentration of $\mathrm{NO}_{2}$. The response $(\mathrm{S})$ for $\mathrm{NO}_{2}$ is calculated as the ratio of the resistance of the $\mathrm{WO}_{3}$ film on gold interdigitated electrodes at different gas concentration and is given by the following equation [26]:

$$
S=\frac{R_{g}}{R_{a}}
$$

where, $\mathrm{R}_{\mathrm{g}}$ is the resistance of the film in presence of $\mathrm{NO}_{2}$ and $\mathrm{R}_{\mathrm{a}}$ is the resistance of the film in air. Metal-oxide gas sensors based on this principle are one of the most studied gas 
sensor types because of its low cost of production, miniature size, low power consumption, and large number of applications [27].

The detailed mechanism of a n-type semiconductor thin film sensor is explained by Franke et al. [28] which can be used as a model to define the interaction between n-type $\mathrm{WO}_{3}$ and $\mathrm{NO}_{2}$. Fig. 1 depicts the mechanism. At elevated temperature, oxygen from the air is adsorbed on the $\mathrm{WO}_{3}$ surface. Since a constant voltage is applied externally on the $\mathrm{WO}_{3}$ film, the electrons are exchanged from the conduction band of $\mathrm{WO}_{3}$ to the adsorbed oxygen causing them to convert to ionosorbed species. $\mathrm{NO}_{2}$ is a strong oxidizer, because of the presence of an unpaired electron in its outermost shell, which supports the formation of ionosorbed oxygen [20] according to the following equations:

$$
\begin{aligned}
& \mathrm{NO}_{2}+\mathrm{e}^{-}=\mathrm{NO}^{+}+\mathrm{O}^{2-} \text { ads }\left(\text { below } 150^{\circ} \mathrm{C}\right), \\
& \mathrm{NO}_{2}+\mathrm{e}^{-}=\mathrm{NO}^{+}+\mathrm{O}^{-} \text {ads }\left(150-500^{\circ} \mathrm{C}\right)[29] .
\end{aligned}
$$

This causes the formation of an electron depletion region around the individual $\mathrm{WO}_{3}$ particle, also known as space-charge layer, $\Lambda_{\text {gas }}$ [30]. At the junction of two particles a larger electron depletion layer $\left(2 * \Lambda_{\mathrm{gas}}\right)$ is formed causing conduction band bending of $\mathrm{WO}_{3}$ and the generation of a surface potential barrier (height of band bending $\mathrm{qV}_{\mathrm{s}}$ ). Since the electronic conduction occurs along a percolation path via particle to particle contact, presence of the large electron depletion region hampers the electron path causing an increase in overall $\mathrm{WO}_{3}$ film resistance.

\footnotetext{
"PLEASE INSERT FIGURE 1"
} 
The gas sensing property of $\mathrm{WO}_{3}$ films strongly depends on the preparation method and the growing conditions of the film itself. Many synthesis procedures have been proposed for producing the $\mathrm{WO}_{3}$ films for $\mathrm{NO}$ and $\mathrm{NO}_{2}$ sensors. These include spray pyrolysis [31], drop coating [32], co-precipitation [33], sol-gel synthesis [20], plasma-enhance chemical vapor deposition (PECVD) [34], thermal evaporation [13, 35], and glancing angle DC magnetron sputtering [36]. In order to have a high productivity, low resistance, and a low power consumption sensor, the current trend is to construct all sensing elements on a chip [37].

Here we have proposed an open atmosphere flame based process also known as Reactive Spray Deposition Technology (RSDT) for the synthesis of $\gamma$ - $\mathrm{WO}_{3}$ films directly on gold interdigitated electrodes. The RSDT process allows the flexibility to create $\gamma-\mathrm{WO}_{3}$ with control of the particle size, porosity and thickness of the film. The sensitivity of porous $\mathrm{WO}_{3}$ increases when the particle size is below its Debye length $\left(\mathrm{L}_{\mathrm{D}}\right)$ which is $25 \mathrm{~nm}$ [38]. RSDT is a subset of flame spray pyrolysis which was developed by Maric et al. [39] for the synthesis of nanoparticles. This process can employ a broad selection of precursors [40-46] compared to conventional vapor-fed flame reactors. In RSDT, nanoparticles are generated in the flame, and then are either directly deposited on the substrate as a film or collected as a nanopowder. This eliminates the intermediate steps of filtration, drying, and calcination. By incorporating a secondary spray system, nanoparticles can also be deposited on various supports such as carbon [47], magneli phase titania [48] and ceria [41-42]. RSDT provides complete control of the nanoparticle size, crystallinity [49], porosity, film thickness, and support concentration [47]. Ability to control the substrate temperature from $20-1000^{\circ} \mathrm{C}$ enables the use of a wide array of substrates [39]. We have successfully used RSDT for the synthesis of various nanomaterials [41, 43, 46, 48-51]. In our previous work, it had been shown that RSDT can be employed for the synthesis of $\mathrm{WO}_{3}$ films with 
precise control of particle size, film morphology, and crystal structure [40]. In this study, we have employed RSDT for the deposition of nano crystalline $\mathrm{WO}_{3}$ thin films directly on a gold interdigitated electrode which is to be assembled into an $\mathrm{NO}_{2}$ sensing device. Here we provide a brief description of the synthesis, fabrication and testing procedure of the $\mathrm{NO}_{2}$ sensor. The microstructure of the tungsten oxide films, and the effect of the film structure, grain size, and the sensor response to the ppm level concentration of $\mathrm{NO}_{2}$ will be described. $\mathrm{NO}_{2}$ response behavior on the tungsten oxide surface at various operating temperatures will also be presented.

The properties of the $\mathrm{WO}_{3}$ film was investigated by X-ray diffraction (XRD), Raman spectroscopy, the Brunauer-Emmett-Teller (BET) method, high resolution transmission electron microscopy (HRTEM), and scanning electron microscopy (SEM). The sensor response was tested from $0.17-5 \mathrm{ppm}$ at different operating temperatures $\left(250-350^{\circ} \mathrm{C}\right)$ to determine the optimum working temperature. The sensor film was ultimately performance tested for $\mathrm{NO}_{2}$ response in the $0.17-5 \mathrm{ppm}$ range at $300^{\circ} \mathrm{C}$. The sensor was further tested for stability for $300 \mathrm{~h}$ in $0.5 \mathrm{ppm} \mathrm{NO}_{2}$ in the air which is 10 times lower than the workplace permissible exposure limit (PEL) as per the Occupational Safety and Health Administration (OSHA) specification. The sensor was tested below the PEL because it is desirable for the workplace atmosphere to remain below the PEL of $\mathrm{NO}_{2}$. In order to check the selectivity, the sensor was also tested for $10 \mathrm{ppm}$ acetone, $100 \mathrm{ppm}$ ethanol, $10-100 \mathrm{ppm} \mathrm{H}_{2}$, and $10 \mathrm{ppm}$ isoprene. We have also compared the test data of $\mathrm{WO}_{3}$ based $\mathrm{NO}_{2}$ sensors prepared by RSDT with the results reported in the literature.

\section{Experimental:}

2.1 Synthesis of $\mathrm{WO}_{3}$ :

An explanation of the RSDT equipment and process has been described in detail by Jain and Roller et al. [41, 44]. Fig. 2 shows the schematic of RSDT along 
with the cross sectional view of the combustion nozzle. Tungsten hexacarbonyl $\left[\mathrm{W}(\mathrm{CO})_{6}\right]$ was obtained from Sigma Aldrich (Catalogue \#AC221040100) and was dissolved in a tetrahydrofuran (THF) (enthalpy of combustion: $2501 \mathrm{~kJ} / \mathrm{mol}$ ) (Fisher Scientific \# SHBD3901V). The precursor was chosen based on its low decomposition temperature of $170^{\circ} \mathrm{C} .20 \mathrm{wt} \%$ sulfur free liquefied propane (Airgas catalogue \# PRCP350S) was added to the above to form a precursor solution resulting in a final concentration of $5 \mathrm{mM} / \mathrm{L} \mathrm{W}(\mathrm{CO})_{6}$, and $18 \mathrm{wt} \%$ propane. THF has a dual role of an inexpensive solvent and fuel for the combustion of the $\left[\mathrm{W}(\mathrm{CO})_{6}\right]$. The precursor solution was filled in a syringe pump (Teledyne Isco 500D) and after heating to $50-60^{\circ} \mathrm{C}$ it was directed through a $4 \mathrm{~mL} / \mathrm{min}$ stainless steel capillary tube of $100 \mu \mathrm{m}$ inner diameter to the combustion nozzle. Six methane-oxygen flamelets (methane and oxygen at $0.5 \mathrm{~L} / \mathrm{min}$ each) surround the capillary end, which ignites the combustible precursor mist. The precursor solution was atomized by oxygen $(5 \mathrm{~L} / \mathrm{min})$ and a pressure drop of 125 psi was maintained at the exit point of the nozzle. At $10 \mathrm{~cm}$ from the combustion nozzle, an circular air quench ring (Exair, Super Air Wipe ${ }^{\circledR}$ ) with a compressed air flow rate of $70 \mathrm{~L} / \mathrm{min}$ was positioned. The distance between the combustion nozzle and the air quench is considered the reaction zone and the length of the reaction zone is proportional to the residence time of the nano-particles in that zone. Adjusting the length of the reaction zone and the flow rate of compressed air gives unique conditions to obtain an assortment of crystalline structures and phases of the material [52]. This also enables "nano quenching" thereby limiting the particle size growth in the flame. Two silicon plates (Nova electronic materials item\#8289) and two gold interdigitated electrodes on alumina base (Electronic design center-Case Western Reserve University item\#102) were used as substrates. Silicon plates were used only to evaluate the film thickness since they can be easily fractured and can be mounted at $90^{\circ}$ on a SEM stub. Gold interdigitated electrodes on alumina base (Electronic design center-Case Western 
Reserve University item\#102) were used as substrates for the gas sensing. This thick film printed electrode consists of interdigitated gold deposits on a $0.6 \mathrm{~mm}$ thick alumina substrate. The dimensions of the alumina base is $15 \mathrm{~mm}$ by $15 \mathrm{~mm}$. The gold thick film screen printed electrode digits are $250 \mu \mathrm{m}$ wide with $250 \mu \mathrm{m}$ spacing between them. The gold digits are connected with a pair of gold bonding pads which allow wires to be threaded through them as an aid for electrical connection. Prior to $\mathrm{WO}_{3}$ deposition, the electrode was cleaned with acetone, methanol and deionized water, in order and dried in an air oven operating at $80^{\circ} \mathrm{C}$ for $1 \mathrm{~h}$. The four substrates were mounted on a stainless steel substrate holder, which was placed on an $x-y-z$ platform. This enabled the substrates to move along a serpentine path in front of the flame to ensure even coating of $\mathrm{WO}_{3}$ on the substrates. The total deposition area was $25 \mathrm{~cm}^{2}$. All the samples were annealed in the air at $500^{\circ} \mathrm{C}$ for $5 \mathrm{~h}$ in an oven to stabilize the $\mathrm{WO}_{3}$ film. The characterization and gas sensing measurements were performed on the post annealed samples.

\section{"PLEASE INSERT FIGURE 2"}

\subsection{Characterization:}

XRD patterns of $\mathrm{WO}_{3}$ films directly deposited on gold interdigitated electrodes were recorded in the air at $25^{\circ} \mathrm{C}$ on a Bruker D8 advanced powder diffractometer using the source: $\mathrm{CuK} \alpha_{1}$ radiation (wavelength: $1.54058 \AA$ ), operating at $40 \mathrm{kV}$ and $40 \mathrm{~mA}$ and the detector: LynxEye, super speed detector. The scans were taken in the $2 \theta$ range of $20-55^{\circ}$ with a step size of $0.02^{\circ}$ and time per step of $5 \mathrm{~s}$. Raman spectra were obtained in air at $25^{\circ} \mathrm{C}$ in the spectral range between 100 and $1200 \mathrm{~cm}^{-1}$ with a Renishaw Ramascope microRaman spectrometer fitted with a reflected light microscope using a $50 \mathrm{~mW}$ laser $(514.5 \mathrm{~nm})$ and exposure time of $10 \mathrm{~s}$. Laser power delivered to the sample was set at $20 \%(10 \mathrm{~mW})$ to avoid sample damage. Instrument alignment was optimized using a $521 \mathrm{~cm}^{-1}$ signal of a silicon wafer. 
Raman measurements for $\mathrm{WO}_{3}$ is well known to provide structural and phase information of $\mathrm{WO}_{3}$ material [53]. The surface area of $\mathrm{WO}_{3}$ particles was calculated by the Brunauer-EmmettTeller (BET) method using $\mathrm{N}_{2}$ sorption experiments on a Micromeritics ASAP 2020 BET system. Samples were degassed for $12 \mathrm{~h}$ prior to $\mathrm{N}_{2}$ sorption measurements. For obtaining the samples for BET, a separate experiment was performed in which, $\mathrm{WO}_{3}$ nanoparticles powder was directly collected on a stainless steel substrate holder. The deposit was scrapped off using a plastic spatula and analyzed for $\mathrm{N}_{2}$ sorption experiments. SEM micrographs were collected on an FEI ESEM Quanta 250 with a field emission gun at $5 \mathrm{kV}$ accelerating voltage and $8 \mathrm{~mm}$ working distance. For determining the cross sectional thickness of the film, the silicon substrate with $\mathrm{WO}_{3}$ film was fractured, and mounted on a $90^{\circ}$ aluminum stub. The sample was gold sputter coated prior to imaging under SEM. TEM micrographs and selected area diffraction pattern (SADP) of $\mathrm{WO}_{3}$ particles were obtained on a $120 \mathrm{kV}$ FEI Tecnai T12 S/TEM with a $\mathrm{LaB}_{6}$ source. HRTEM micrographs were obtained on a $200 \mathrm{kV}$ FEI Metrios TEM with an X-FEG source. 300 mesh Cu grids coated with holey/thin carbon films (Pacific Grid Tech $\mathrm{Cu}-300 \mathrm{HD}$ ) were used. A small portion of the film was scraped off from the gold interdigitated electrodes and was sonicated with ethanol. Few drops of the resulting solution were dropped on the grids and air dried before they were placed in the ultra-high vacuum (UHV) chamber of the TEM.

\subsection{Gas sensing test:}

Gas sensing tests were performed in a dynamic flow system, implemented in the laboratory as shown in Fig. 3. Prior to gas sensing, the electrode was annealed in the air at $500^{\circ} \mathrm{C}$ for $5 \mathrm{~h}$ in an electric oven to stabilize the $\mathrm{WO}_{3}$ film. $\mathrm{A} \mathrm{WO}_{3}$ coated gold interdigitated electrode was introduced in a quartz cylindrical test chamber $(10 \mathrm{~cm}$ length and 3.2 cm inner diameter) which was wrapped by a high temperature nozzle band heater (McMaster 
Carr item\# 3594K981). The ends of the test chamber were sealed by stainless steel fittings. Several ports were introduced in the test chamber for (1) gas inlet, (2) 2 gas outlets, and (3) standard k-type thermocouple to monitor temperature. Gas flow to the furnace was controlled by Environics Series 4040 Computerized Gas Dilution System with an option for precise humidification control $(0-100 \%$ relative humidity at a given temperature). Presence of 2 gas outlets in the test chamber allows a precisely controlled change in the atmosphere of the test chamber, as soon as the gas concentration is changed from $\mathrm{NO}_{2}$ to pure air and vice versa. Dry synthetic air (Airgas \#AI UZ300) was used as a diluent gas and $10 \mathrm{ppm} \mathrm{NO}_{2}$ in the air (Airgas $\#$ X02AI99C15A2520) was used for adjusting the $\mathrm{NO}_{2}$ concentration. Humidity level of $100 \%$ r.h. was maintained throughout the tests at the gas inlet to the test chamber as measured by a calibrated hygrometer (Vaisala HMT 337). The water vapor pressure of the test gas at the inlet of the heated test chamber was 23.7 torr. Flow rate of $1.5 \mathrm{~L} / \mathrm{min}$ was maintained in the test chamber. For the two probe amperiometric measurements, the $\mathrm{WO}_{3}$ coated electrode was connected with two Pt wires (99.9\% metals basis) (0.127 mm diameter) (Alfa Aesar\#F20X038) and connected with a CHI instrument's electrochemical analyzer (CHI6116E). Current (I) was measured as a function of time and gas flow concentration at a constant $1 \mathrm{~V}$ DC power supply. Resistance $(\mathrm{R})$ was calculated by applying Ohm's law $(\mathrm{R}=\mathrm{V} / \mathrm{I})$. The data was collected every $100 \mathrm{~ms}$.

\section{“PLEASE INSERT FIGURE 3"}

\section{Results:}

\subsection{Structural properties}

\subsubsection{X-ray diffraction $(X R D)$ :}


Fig. 4 (a) shows the XRD pattern of the

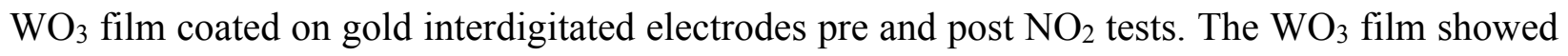
the monoclinic structure and was indexed to ICDD\#01-043-1035. The characteristic main peaks for $\gamma-\mathrm{WO}_{3}$ were seen at the $2 \theta$ value of $23.2^{\circ}, 23.6^{\circ}$ and $24.4^{\circ}$ and can be associated with the (002), (020) and (200) reflections respectively. Average crystallite size of $\mathrm{WO}_{3}$ was calculated from Xray line broadening by Debye Scherrer's method and was $21 \mathrm{~nm}$ on the as prepared sample, and $27 \mathrm{~nm}$ on the post $\mathrm{NO}_{2}$ test samples. As seen from the XRD pattern, there was an increase in the intensity of the $\mathrm{WO}_{3}$ film post $\mathrm{NO}_{2}$ tests. This could be due to the increase in crystallinity of the $\mathrm{WO}_{3}$ particles under the high temperature of testing. However no change in the overall structure of the film was observed verifying that the film was stable under the $\mathrm{NO}_{2}$ test conditions.

\section{"PLEASE INSERT FIGURE 4"}

\subsubsection{Raman spectroscopy:}

Raman spectroscopy technique was used for identifying the phases in the $\mathrm{WO}_{3}$ film since this technique is well known to give the "fingerprint "of $\mathrm{WO}_{3}$ material [53]. Fig. 4 (b) shows the Raman spectroscopy results of the $\mathrm{WO}_{3}$ film directly deposited on gold interdigitated electrodes, both pre and post $\mathrm{NO}_{2}$ tests. The strongest peaks were seen at 808 and $715 \mathrm{~cm}^{-1}$ which are similar to those of the monoclinic $\gamma-\mathrm{WO}_{3}$. A relatively strong peak was observed below $150 \mathrm{~cm}^{-1}$ for all the samples which indicates the $\mathrm{O}-\mathrm{O}$ deformation mode [54]. Intensity of the $\mathrm{WO}_{3}$ film after $\mathrm{NO}_{2}$ sensing has increased, consistent with the $\mathrm{XRD}$ results. On the basis of XRD and Raman spectroscopy results, it can be safely concluded that the structure of the $\mathrm{WO}_{3}$ film in this study is monoclinic $\gamma$ phase.

\subsubsection{Electron microscopy (SEM and TEM):}


Fig. 5 (a), (b) and (c) shows the SEM micrographs of the $\mathrm{WO}_{3}$ film as deposited on a $\mathrm{Si}$ wafer and gold electrode. The $\mathrm{Si}$ wafer was the chosen as a substrate because it can be easily fractured which enables the examination of the $\mathrm{WO}_{3}$ film cross section. From Fig. 5 (a) the film thickness was measured to be $2.5 \mu \mathrm{m}$. Fig. 5 (b) shows the $\mathrm{WO}_{3}$ film directly deposited on the gold interdigitated electrode. Uniformly coated gold lines with $\mathrm{WO}_{3}$ can be seen and it can be inferred that the film formation is conformal in nature. From Fig. 5 (c) it can be inferred that the $\mathrm{WO}_{3}$ film surface is rough and porous with the formation of some agglomerates around 5-10 $\mu \mathrm{m}$ wide. Various open pores could be seen which is advantageous for the diffusion of gases in the bulk of the film [55]. The total $\mathrm{WO}_{3}$ deposition area on the gold electrodes was $97.5 \mathrm{~mm}^{2}$. The surface to volume ratio of the $\mathrm{WO}_{3}$ film was $400 \mathrm{~mm}^{-1}$. The images indicate high quality porous $\mathrm{WO}_{3}$ films deposited by RSDT without any cracks, voids, dense regions or surface abnormalities.

\section{“PLEASE INSERT FIGURE 5"}

Fig. 5 (d) and (e) shows the bright field TEM and HRTEM micrographs of the $\mathrm{WO}_{3}$ particles. Various oval shaped particles can be seen. From TEM point analysis, a particle size $\left(\mathrm{d}_{\mathrm{TEM}}\right)$ distribution ranging between 20-30 nm was observed. No evidence of sintering of the nanoparticles was found which is attributed to the use of air quench in RSDT. The selected area diffraction patterns (SADP) of $\mathrm{WO}_{3}$ is shown in the inset of Fig. 5 (d). The brightest diffraction ring corresponds to the (002), (220) and (114) planes. Fig. 5 (e) shows the HRTEM micrograph of one of the particle with the lattice fringes clearly visible. The lattice fringe spacing corresponds to the (002) plane of $\gamma-\mathrm{WO}_{3}$.

\subsubsection{BET surface area:}




$$
\mathrm{N}_{2} \text { sorption measurements were }
$$

performed for the $\mathrm{WO}_{3}$ powder and the surface area was calculated by the BET method. The BET surface area was calculated as $46 \mathrm{~m}^{2} / \mathrm{g}$. An average particle diameter was estimated using the BET surface area and the density of $\mathrm{WO}_{3}(7.16 \mathrm{~g} / \mathrm{cc})$ by making the assumption that the particles are uniformly sized spheres. Particle diameter $\left(\mathrm{d}_{\mathrm{BET}}\right)$ was calculated to be $18 \mathrm{~nm}$.

\subsection{Response dependence on temperature:}

The $\mathrm{WO}_{3}$ film was tested for $\mathrm{NO}_{2}$ response in the range of 0.17 ppm to 5 ppm between $275-350^{\circ} \mathrm{C}$ to establish the relationship between $\mathrm{NO}_{2}$ concentration and temperature, and to determine the working temperature at which the best response can be obtained. Fig. 6 (a) shows this relationship. It can be seen that as the temperature is increased, the response increases till it reaches the maximum value at $300^{\circ} \mathrm{C}$. If the temperature is further increased, the response is reduced. This could be due to increased desorption of $\mathrm{NO}_{2}$ at high temperature which reduces the concentration of ionosorbed oxygen at the $\mathrm{WO}_{3}$ surface.

\section{“PLEASE INSERT FIGURE 6”}

\subsection{Gas sensing results:}

Fig. 6 (b) shows the normalized response-recovery curve vs time for the $\mathrm{NO}_{2}$ concentration ranging from $0.17-5 \mathrm{ppm}$ in the air at $100 \%$ at $300^{\circ} \mathrm{C}$. The measurable limit for our tests was $0.17 \mathrm{ppm}$. The response increases as the concentration of $\mathrm{NO}_{2}$ is increased. This is because of the increased adsorption of $\mathrm{NO}_{2}$ molecules at higher $\mathrm{NO}_{2}$ concentration. The adsorption and desorption of the $\mathrm{NO}_{2}$ molecules on the $\mathrm{WO}_{3}$ film takes place simultaneously and is a reversible process. During the response stage, adsorption is higher than desorption and the resistance of the film increases. This is because $\mathrm{NO}_{2}$ diffuses through the porous $\mathrm{WO}_{3}$ film and 
oxidizes the $\mathrm{WO}_{3}$ surface thereby increasing the ionosorbed oxygen concentration of the film. This causes an increase in electron scattering sites. $\mathrm{NO}_{2}$ also captures electrons from the conduction band of $\mathrm{WO}_{3}$ causing the formation of an electron depletion region, triggering an increase in its resistance. It was seen that the sensor response was spontaneous as the gas concentration in the test chamber was changed from pure air to $\mathrm{NO}_{2}$ in the air. The response time was calculated to be $7.2 \mathrm{~s}$. The sensor stabilized at the maximum value of resistance, very quickly. At this point, the adsorption rate is equal to the desorption rate. Maximum adsorption had taken place at that particular analyte concentration and the $\mathrm{WO}_{3}$ film was in equilibrium with the $\mathrm{NO}_{2}$ molecules. Recovery of the sensor started when pure air was switched back to the test chamber. At this point, adsorption was nil and desorption was the only process which was taking place. Presence of two vents in the test chamber expedited the exchange of the gas atmosphere. However it was seen that desorption was still slower than adsorption. A drift can be seen when the resistance of the film is measured in air after exposure to $\mathrm{NO}_{2}$ at different concentrations. This is caused because of incomplete recovery during the 5 minute of recovery phase.

\subsection{Stability tests:}

Stability tests of the $\mathrm{WO}_{3}$ films were conducted for $300 \mathrm{~h}$ at 0.5 ppm $\mathrm{NO}_{2}$ in the air which was maintained at $100 \%$ relative humidity at $25^{\circ} \mathrm{C}$ prior to being sent to the test chamber. This concentration of $\mathrm{NO}_{2}$ is 10 times lower than the workplace permissible exposure limit (PEL) as per the Occupational Safety and Health Administration (OSHA) specification. The sensor was tested below the PEL because it is desirable for the workplace atmosphere to remain below the PEL of $\mathrm{NO}_{2} .0 .5 \mathrm{ppm} \mathrm{NO}_{2}$ was switched on every 5 minutes (response) followed by 5 minutes of pure air (recovery). Resistance of the film was measured every $100 \mathrm{~ms}$ to record the response and recovery cycle (response + recovery time $=10 \mathrm{~min})$. A total of 
2000 response-recovery cycles were recorded. Fig. 7 shows the resistance over time for $\mathrm{WO}_{3}$ film in pure air $\left(\mathrm{R}_{\mathrm{a}}\right)$ and $0.5 \mathrm{ppm} \mathrm{NO}$ in air $\left(\mathrm{R}_{\mathrm{g}}\right)$ respectively. The resistance is calculated as the moving average for the data collected every $24 \mathrm{~h}$. It can be seen that the sensor is stable till day $6(\sim 150$ h). From day 6-14 (150-300 h) the sensor began to degrade possibly due to the growth of the $\mathrm{WO}_{3}$ nanoparticles. This shows that maximum degradation of the sensor occurred after day $8(\sim 200 \mathrm{~h})$ as evident from the fluctuation of resistance.

\section{“PLEASE INSERT FIGURE 7”}

\subsection{Selectivity:}

The response of $1 \mathrm{ppm} \mathrm{NO}_{2}$ was compared with $10 \mathrm{ppm}$ acetone, $100 \mathrm{ppm}$ ethanol, $10-100 \mathrm{ppm} \mathrm{H}_{2}$ and $10 \mathrm{ppm}$ isoprene at $0.5 \mathrm{ppm} \mathrm{NO} \mathrm{N}_{2}$ in air. This is shown in Fig. 8. It can be seen that the sensor had negligible response for acetone, ethanol and $10 \mathrm{ppm}_{2}$. However, the response is significant for $100 \mathrm{ppm}_{2}$ and $10 \mathrm{ppm}$ isoprene. Isoprene and $\mathrm{H}_{2}$ are some of the major component exhaled from the human breath [56]. Typical values of isoprene in the breath of a healthy human range from $0.012-0.58 \mathrm{ppm}$ [57] while $\mathrm{H}_{2}$ range from 10-20 ppm [58].

\section{“PLEASE INSERT FIGURE 8”}

\section{Discussions:}

On the basis of the characterization and gas sensing results, we can conclude that RSDT can be used for the synthesis of $\mathrm{NO}_{2}$ sensing films directly on gold interdigitated electrodes. Based on our previous work on $\mathrm{WO}_{3}[40]$ and a review of the literature, it can be shown that the characteristics of the sensing device that are most important for good performance are: (1) high porosity of the sensing film, (2) particle size of the sensing film smaller than the Debye length $\left(\mathrm{L}_{\mathrm{D}}\right)$, a characteristic of the semiconductor material, which is $25 \mathrm{~nm}$ for $\mathrm{WO}_{3}$, (3) film thickness, 
(4) absence of impurities in the test atmosphere, (5) test chamber volume, and (6) time required for the exchange of gases in the test chamber. In this discussion we will identify the importance of these factors and show that the gas sensing test data presented in this work adheres to these requirements. We have also shown the comparison between the RSDT synthesized sensors and the sensors synthesized by other techniques as shown in table 1 .

\section{“PLEASE INSERT TABLE 1"}

Since the sensing is an adsorption-desorption process, gas diffusion through the film plays a major role in the sensor performance. The sensing film must be porous to effectively allow the diffusion process and extend the reaction between $\mathrm{NO}_{2}$ and oxygen from the surface to the bulk. By assuming steady state conditions, it can be interpreted that the $\mathrm{NO}_{2}$ concentration decreases with the film depth which causes the formation of various degree of reactions at different depths of the film. The resistance change data recorded by the electrochemical analyzer averages the resistances by providing the overall resistance change of the film. Ideally it would be beneficial to eliminate this variation. Film porosity, thickness, microstructure, and the electrode pattern are the factors which govern this variation [59-60]. From the SEM micrographs in Fig. 5 (c) it can be seen that the $\mathrm{WO}_{3}$ film synthesized by RSDT is highly porous and uniform.

Gas sensing response is dependent on the particle size of the sensing film. Smaller particles and increased surface area (higher surface to volume ratio) provides larger number of sites for the surface reaction to occur. At the same time, reducing the particle radius below $\Lambda_{\text {gas, }}$ will converge the electron depletion layer $\left(2 \Lambda_{\text {gas }}\right)$ and the electrical conduction will be dominated by the presence of adsorbed $\mathrm{NO}_{2}^{-} . \Lambda_{\text {gas }}$ depends on the Debye length $\left(\mathrm{L}_{\mathrm{D}}\right)$ of the material which is 
$25 \mathrm{~nm}$ for $\mathrm{WO}_{3}$. Sharma et al. has described the relationship between gas sensor response and particle size with respect to the Debye length $\left(L_{D}\right)$. When the particle size is smaller than $L_{D}$, the ionosorbed oxygen will extract all the electrons from the $\mathrm{WO}_{3}$ particle causing an increase in film resistance [30]. It was also shown by Tamaki et al. that the sensor response of $\mathrm{WO}_{3}$ particles at 10 ppm $\mathrm{NO}_{2}$ were three fold higher when the particle size was smaller than $25 \mathrm{~nm}$ as compared to particles larger than $33 \mathrm{~nm}$ [38]. In this work, the $\mathrm{WO}_{3}$ particle size were in the range $20-30 \mathrm{~nm}$ as determined by the TEM point analysis in Fig. 5 (d). BET surface area measurements revealed the average particle diameter $\left(\mathrm{d}_{\mathrm{BET}}\right)$ to be $18 \mathrm{~nm}$.

Working temperature is an important factor responsible for the performance of the sensor since sensing is an adsorption desorption process which is also influenced by kinetics [61]. At low working temperature, the activation barrier for the generation of ionosorbed oxygen is higher, while at high temperature, the desorption of $\mathrm{NO}_{2}$ exceeds adsorption resulting in lower response. Hence the optimum temperature at with balance kinetics and desorption is essential. In this work, the highest response was obtained at $300^{\circ} \mathrm{C}$.

Selectivity with other gases is a major concern for a sensor to be commercially viable, which can lead to false alarm or incorrect gas concentration determination. In this study, it was found that the $\mathrm{WO}_{3}$ film was responsive towards $10 \mathrm{ppm}$ isoprene and $100 \mathrm{ppm} \mathrm{H}_{2}$, while the response towards $10 \mathrm{ppm}$ acetone, $100 \mathrm{ppm}$ ethanol and $10 \mathrm{ppm} \mathrm{H}_{2}$ was negligible. All the tests were performed in $100 \%$ relative humidity of the gas, which was maintained upstream of the test chamber, and cross-sensitivity towards $\mathrm{H}_{2} \mathrm{O}$ was not observed. There are various methods suggested in the literature to discriminate the interference towards these gases. The most common approach is to utilize a sensor array described by Albert et al. with various sensor electrodes to filter out the response from the interfering analytes [62]. The other method is to use filters upstream 
of the electrode to filter out the gases. One such activated charcoal filter is used by Figaro Inc. in their commercial CO sensor - TGS5042. Since the sensor response is a diffusion driven process, it can be easily applied to improve the selectivity. Porous layers in which gases may have different diffusion coefficient can be directly deposited on the sensing layer. These layers acts as molecular sieves to reject the interfering gases. Description of these porous layer filters have been provided in details in this reference [63].

The long recovery time and the drift of the metal oxides based sensors have been long recognized and various suggestions to counter this limitation have been proposed. From the gas sensing tests in Fig. 6 (b), a drift can be seen when the resistance of the film is measured in the air after exposure to $\mathrm{NO}_{2}$ at different concentrations. This is caused because of incomplete recovery during the 5 minute of recovery phase. As a gas molecule is chemically adsorbed on the surface of $\mathrm{WO}_{3}$, it is in thermal equilibrium and resides at the bottom of the potential well (minimum potential energy). In order to desorb from the surface, the only driving force it experiences is the diffusion caused by the change in the concentration of gases in the test chamber on switching to pure air. However this energy is not sufficient and causes a long delay to achieve complete desorption. Further thermal or electrical energy is required to expedite this adsorption process. Different ways are suggested in literature to eliminate sensor drift. These include, using high-speed gas-switching system and smaller volume test chamber for enabling quicker gas exchange [64] pre exposing the sensing film to the analyte for a set period of time [65], use of mathematical function and modelling [66] to pre-estimate the steady state conditions and remove the time lag [67], use of multiple sensing electrodes in different test chamber to alter between response and recovery [68], use of neural network algorithm for the sensor to "self-learn" [69] use of strong negative field to electro-desorb the residual analyte molecules to "refresh" the sensor 
[70] and by illuminating the sensor with ultra-violet (UV) light [71]. Here we have used a two vent test chamber to expedite the atmosphere change. The test chamber volume was $80 \mathrm{cc}$. We are currently developing a prototype sensing device with a volume of $0.5 \mathrm{cc}$ which will further eliminate this issue.

\section{Conclusions}

In this study we have evaluated RSDT as a direct deposition technique for the synthesis of $\gamma$ $\mathrm{WO}_{3}$ film for ultra-low $\mathrm{NO}_{2}$ sensing. Nano quenching was used to optimize the particle size and film morphology to tailor the film towards superior $\mathrm{NO}_{2}$ sensing performance. Here our main objective was to correlate the influence of the synthesis process, and the resultant structural properties of the $\gamma-\mathrm{WO}_{3}$ film with the $\mathrm{NO}_{2}$ gas sensing performance. We have highlighted these properties and their influence on the $\mathrm{NO}_{2}$ sensing which will provide a platform for developing better sensors with improved performance compared to the currently used sensors. The reasons for the high response can be attributed to a number of factors, such particle size, porosity and pore size, and film thickness, all precisely controlled by the RSDT. Following conclusions can be made from this work:

1. RSDT synthesized $\mathrm{WO}_{3}$ film based $\mathrm{NO}_{2}$ sensor was responsive in the $0.17-5 \mathrm{ppm}$ range, when tested at $300^{\circ} \mathrm{C}$.

2. Response time was $7.2 \mathrm{~s}$ and recovery time was greater than 5 minutes. The response time was better than the $\mathrm{WO}_{3}$ sensors synthesized by the traditional wet chemistry processes from literature.

3. The response was highest at the working temperature of $300^{\circ} \mathrm{C}$.

4. The $\mathrm{NO}_{2}$ sensors gave a steady response till $150 \mathrm{~h}$ of continuous performance and started to degrade after $200 \mathrm{~h}$ possibly due to increase in particle size. 
5. Interference was negligible with $10 \mathrm{ppm}$ acetone, $100 \mathrm{ppm}$ ethanol, $10 \mathrm{ppm}_{2}$ and humidity; however, it was significant with $10 \mathrm{ppm}$ isoprene and $100 \mathrm{ppm} \mathrm{H}_{2}$.

6. Response and recovery of the sensor is caused by adsorption and desorption respectively. Hence recovery time can be improved by expediting the desorption step.

7. $\mathrm{WO}_{3}$ particle size of $<25 \mathrm{~nm}$ attributes to better charge transfer which translates to superior $\mathrm{NO}_{2}$ sensitivity.

\section{Acknowledgements}

Authors would like to acknowledge financial support from National Science Foundation (award number CMMI-1265893). We would like to acknowledge Dr. Justin Roller at FEI Company for the HRTEM micrograph. The creative discussion with Mr. Leonard Bonville is highly appreciated. R.J. acknowledges the 2015 General Electric (GE) graduate fellowship.

\section{References:}

[1] G.A. Bishop, D.H. Stedman, Measuring the Emissions of Passing Cars, Acc. Chem. Res. 29 (1996) 489-495.

[2] H. Klonoff-Cohen, P.K. Lam, A. Lewis, Outdoor carbon monoxide, nitrogen dioxide, and sudden infant death syndrome, Arch. Dis. Child. 90 (2005) 750-753.

[3] U. Bauer, D. Berg, M.A. Kohn, R.A. Meriwether, R.A. Nickle, Acute effects of nitrogen dioxide after accidental release, Public Health Rep. 113 (1998) 62-70.

[4] O. B. Crofford, R. E. Mallard, R. E. Winton, N. L. Rogers, J. C. Jackson, and U. Keller, Acetone in breath and blood, Trans. Am. Clin. Climatol. Assoc. 88 (1977) 128-139. 
[5] K.L. Demerjian, A review of national monitoring networks in North America, Atmos. Environ. 34 (2000) 1861-1884.

[6] H. Edner, P. Ragnarson, S. Spännare, S. Svanberg, Differential optical absorption spectroscopy (DOAS) system for urban atmospheric pollution monitoring, Appl. Opt. 32 (1993) $327-333$.

[7] J.A. Thornton, P.J. Wooldridge, R.C. Cohen, Atmospheric $\mathrm{NO}_{2}$ : In Situ Laser-Induced Fluorescence Detection at Parts per Trillion Mixing Ratios, Anal. Chem. 72 (2000) 528-539.

[8] T. Stacewicz, J. Wojtas, Z. Bielecki, M. Nowakowski, J. Mikołajczyk, R. Mędrzycki, B. Rutecka, Cavity ring down spectroscopy: detection of trace amounts of substance, Opto-Electron Rev. 20 (2012) 53-60.

[9] G. Villena, I. Bejan, R. Kurtenbach, P. Wiesen, J. Kleffmann, Development of a new Long Path Absorption Photometer (LOPAP) instrument for the sensitive detection of $\mathrm{NO}_{2}$ in the atmosphere, Atmos. Measurement Techniques. 4 (2011) 1663-1676.

[10] Y. Guan, C. Li, X. Cheng, B. Wang, R. Sun, X. Liang, J. Zhao, H. Chen, G. Lu, Highly sensitive mixed-potential-type $\mathrm{NO}_{2}$ sensor with $\mathrm{YSZ}$ processed using femtosecond laser direct writing technology, Sens. Actuators B: Chem. 198 (2014) 110-113.

[11] S. Yao, J.R. Stetter, Modification of NASICON Solid Electrolyte for $\mathrm{NO}_{\mathrm{x}}$ Measurements, J. Electrochem. Soc. 151 (2004) H75-H80.

[12] L. Gao, Z. Cheng, Q. Xiang, Y. Zhang, J. Xu, Porous corundum-type $\mathrm{In}_{2} \mathrm{O}_{3}$ nanosheets: Synthesis and $\mathrm{NO}_{2}$ sensing properties, Sens. Actuators B: Chem. 208 (2015) 436-443. 
[13] T. Siciliano, A. Tepore, G. Micocci, A. Serra, D. Manno, E. Filippo, $\mathrm{WO}_{3}$ gas sensors prepared by thermal oxidization of tungsten, Sens. Actuators B: Chem. 133 (2008) 321-326.

[14] W.L. Kehl, R.G. Hay, D. Wahl, The Structure of Tetragonal Tungsten Trioxide, J. Appl. Phys. 23 (1952) 212-215.

[15] E.K.H. Salje, The orthorhombic phase of $\mathrm{WO}_{3}$, Acta Crystallogr B. 33 (1977) 574.

[16] E.K.H. Salje, S. Rehmann, F. Pobell, D. Morris, K.S. Knight, T. Herrmannsdörfer, M.T. Dove, Crystal structure and paramagnetic behaviour of $\varepsilon-\mathrm{WO}_{3-\mathrm{x}}$, J. Phys-Condens. Mat. 9 (1997) 6563.

[17] R. Diehl, G. Brandt, E. Salje, The crystal structure of triclinic $\mathrm{WO}_{3}$, Acta Crystallogr. B. B34 (1978) 1105-1111.

[18] M.Z. Ahmad, J.H. Kang, A.Z. Sadek, A. Moafi, G. Sberveglieri, W. Wlodarski, Synthesis of $\mathrm{WO}_{3}$ Nanorod based Thin Films for Ethanol and $\mathrm{H}_{2}$ Sensing, Procedia Eng. 47 (2012) 358-361.

[19] Z.Y. Sun, H.Q. Yuan, Z.M. Liu, B.X. Han, X.R. Zhang, A highly efficient chemical sensor material for $\mathrm{H}_{2} \mathrm{~S}$ : alpha- $\mathrm{Fe}_{2} \mathrm{O}_{3}$ nanotubes fabricated using carbon nanotube templates, $\mathrm{Adv}$ Mater. 17 (2005) 2993-2997.

[20] P.I. Gouma, K. Kalyanasundaram, A selective nanosensing probe for nitric oxide, Appl. Phys. Lett. 93 (2008) 244102.

[21] V. Srivastava, K. Jain, Highly sensitive $\mathrm{NH}_{3}$ sensor using Pt catalyzed silica coating over $\mathrm{WO}_{3}$ thick films, Sens. Actuators B: Chem. 133 (2008) 46-52. 
[22] M. Bendahan, R. Boulmani, J.L. Seguin, K. Aguir, Characterization of ozone sensors based on $\mathrm{WO}_{3}$ reactively sputtered films: influence of $\mathrm{O}_{2}$ concentration in the sputtering gas and working temperature, Sens. Actuators B: Chem. 100 (2004) 320-324.

[23] M.I. Baraton, L. Merhari, H. Ferkel, J.F. Castagnet, Comparison of the gas sensing properties of tin, indium and tungsten oxides nanopowders: carbon monoxide and oxygen detection, Mat. Sci. Eng. C. 19 (2002) 315-321.

[24] M. Righettoni, A. Tricoli, S.E. Pratsinis, Thermally Stable, Silica-Doped $\varepsilon-\mathrm{WO}_{3}$ for Sensing of Acetone in the Human Breath, Chem. Mater. 22 (2010) 3152-3157.

[25] L. Wang, A. Teleki, S.E. Pratsinis, P.I. Gouma, Ferroelectric $\mathrm{WO}_{3}$ Nanoparticles for Acetone Selective Detection, Chem. Mater. 20 (2008) 4794-4796.

[26] C.D. Kohl, Nanoelectronics and Information Technology, in: R. Waser (Ed.), Electronic Noses, Wiley-VCH, Berlin, 2005, pp. 835-864.

[27] C. Wang, L. Yin, L. Zhang, D. Xiang, R. Gao, Metal Oxide Gas Sensors: Sensitivity and Influencing Factors, Sensors (Basel, Switzerland). 10 (2010) 2088-2106.

[28] M.E. Franke, T.J. Koplin, U. Simon, Metal and metal oxide nanoparticles in chemiresistors: does the nanoscale matter? Small. 2 (2006) 36-50.

[29] N. Barsan, U. Weimar, Conduction Model of Metal Oxide Gas Sensors, J. Electroceram. 7 (2001) 143-167. 
[30] S. Sharma, M. Madou, A new approach to gas sensing with nanotechnology, Phil. Trans. R. Soc. A. 370 (2012) 2448-2473.

[31] V.V. Ganbavle, S.V. Mohite, G.L. Agawane, J.H. Kim, K.Y. Rajpure, Nitrogen dioxide sensing properties of sprayed tungsten oxide thin film sensor: Effect of film thickness, J. Colloid Interface Sci. 451 (2015) 245-254.

[32] T. Akamatsu, T. Itoh, N. Izu, W. Shin, $\mathrm{NO}$ and $\mathrm{NO}_{2}$ Sensing Properties of $\mathrm{WO}_{3}$ and $\mathrm{Co}_{3} \mathrm{O}_{4}$ Based Gas Sensors, Sensors (Basel, Switzerland). 13 (2013) 12467-12481.

[33] D.S. Lee, S.D. Han, S.M. Lee, J.S. Huh, D.D. Lee, The $\mathrm{TiO}_{2}$-adding effects in $\mathrm{WO}_{3}$-based $\mathrm{NO}_{2}$ sensors prepared by coprecipitation and precipitation method, Sens. Actuators B: Chem. 65 (2000) 331-335.

[34] M.S. Tong, G.R. Dai, Y.D. Wu, X.L. He, D.S. Gao, $\mathrm{WO}_{3}$ thin film prepared by PECVD technique and its gas sensing properties to $\mathrm{NO}_{2}$, J. Mater. Sci. 36 (2001) 2535-2538.

[35] W. Gao, Y. Ling, X. Liu, J. Sun, Simple point contact $\mathrm{WO}_{3}$ sensor for $\mathrm{NO}_{2}$ sensing and relevant impedance analysis, Int. J. Min. Met. Mater. 19 (2012) 1142-1148.

[36] M. Horprathum, K. Limwichean, A. Wisitsoraat, P. Eiamchai, K. Aiempanakit, P. Limnonthakul, N. Nuntawong, V. Pattantsetakul, A. Tuantranont, P. Chindaudom, $\mathrm{NO}_{2}$-sensing properties of $\mathrm{WO}_{3}$ nanorods prepared by glancing angle DC magnetron sputtering, Sens. Actuators B: Chem. 176 (2013) 685-691.

[37] G. García J., C.A. Jara, J. Pomares, A. Alabdo, L.M. Poggi, F. Torres, A Survey on FPGABased Sensor Systems: Towards Intelligent and Reconfigurable Low-Power Sensors for 
Computer Vision, Control and Signal Processing, Sensors (Basel, Switzerland). 14 (2014) 62476278.

[38] J. Tamaki, Z. Zhang, K. Fujimori, M. Akiyama, T. Harada, N. Miura, N. Yamazoe, GrainSize Effects in Tungsten Oxide-Based Sensor for Nitrogen Oxides, J. Electrochem. Soc. 141 (1994) 2207-2210.

[39] R. Maric, J. Roller, R. Neagu, Flame-Based Technologies and Reactive Spray Deposition Technology for Low-Temperature Solid Oxide Fuel Cells: Technical and Economic Aspects, J. Therm. Spray Techn. 20 (2011) 696-719.

[40] R. Jain, Y. Wang, R. Maric, Tuning of $\mathrm{WO}_{3}$ Phase Transformation and Structural Modification by Reactive Spray Deposition Technology, J. Nanotech. Smart. Mater. 1 (2014) 17.

[41] R. Jain, R. Maric, Synthesis of nano-Pt onto ceria support as catalyst for water-gas shift reaction by Reactive Spray Deposition Technology, Appl. Catal. A: Gen. 475 (2014) 461-468.

[42] R. Jain, A.S. Poyraz, D.P. Gamliel, J. Valla, S.L. Suib, R. Maric, Comparative study for low temperature water-gas shift reaction on Pt/ceria catalysts: Role of different ceria supports, Appl. Catal. A: Gen. 507 (2015) 1-13.

[43] J. Roller, H. Yu, M.B. Vukmirovic, S. Bliznakov, P.G. Kotula, C.B. Carter, R.R. Adzic, R. Maric, Flame-Based Synthesis of Core-Shell Structures Using Pd-Ru and Pd Cores, Electrochim. Acta. 138 (2014) 341-352. 
[44] J.M. Roller, J. Arellano-Jiménez, R. Jain, H. Yu, R. Maric, C.B. Carter, Processing, Activity and Microstructure of Oxygen Evolution Anodes Prepared by a Dry and Direct Deposition Technique, ECS Trans. 45 (2013) 97-106.

[45] K. Fatih, R. Neagu, V. Alazate, V. Neburchilov, R. Maric, W. Haijiang, Activity of Pt-Sn Catalyst Prepared by Reactive Spray Deposition Technology for Ethanol Electro-oxidation, ECS Trans. 25 (2009) 1177-1183.

[46] J.M. Roller, H. Yu, L. Zhang, P. Plachinda, M.B. Vukmirovic, S. Bliznakov, M. Li, R.R. Adzic, R. Maric, Evaluation of Phase Segregation in Ternary Pt-Rh-SnO 2 Catalysts Prepared from the Vapor Phase, Microsc. Microanal. 20 (2014) 462-463.

[47] H. Yu, J.M. Roller, W.E. Mustain, R. Maric, Influence of the ionomer/carbon ratio for lowPt loading catalyst layer prepared by reactive spray deposition technology, J. Power Sources. 283 (2015) 84-94.

[48] J.M. Roller, M.J. Arellano-Jiménez, H. Yu, R. Jain, C.B. Carter, R. Maric, Catalyst nanoscale assembly from the vapor phase on corrosion resistant supports, Electrochim. Acta. 107 (2013) 632-655.

[49] J. Roller, J. Renner, H. Yu, C. Capuano, T. Kwak, Y. Wang, C.B. Carter, K. Ayers, W.E. Mustain, R. Maric, Flame-based processing as a practical approach for manufacturing hydrogen evolution electrodes, J. Power Sources. 271 (2014) 366-376. 
[50] H. Yu, J.M. Roller, S. Kim, Y. Wang, D. Kwak, R. Maric, One-Step Deposition of Catalyst Layers for High Temperature Proton Exchange Membrane Fuel Cells (PEMFC), J. Electrochem. Soc. 161 (2014) F622-F627.

[51] J.M. Roller, M. Josefina Arellano-Jiménez, R. Jain, H. Yu, C. Barry Carter, R. Maric, Oxygen Evolution during Water Electrolysis from Thin Films Using Bimetallic Oxides of Ir-Pt and Ir-Ru, J. Electrochem. Soc. 160 (2013) F716-F730.

[52] J. Roller, J. Renner, H. Yu, C. Capuano, T. Kwak, Y. Wang, C.B. Carter, K. Ayers, W.E. Mustain, R. Maric, Flame-based processing as a practical approach for manufacturing hydrogen evolution electrodes, J. Power Sources. 271 (2014) 366-376.

[53] C. Bittencourt, E. Llobet, P. Ivanov, X. Vilanova, X. Correig, M.A.P. Silva, L.A.O. Nunes, J.J. Pireaux, Ag induced modifications on $\mathrm{WO}_{3}$ films studied by AFM, Raman and x-ray photoelectron spectroscopy, J. Phys. D. Appl. Phys. 37 (2004) 3383-3391.

[54] M. Arai, S. Hayashi, K. Yamamoto, S.S. Kim, Raman Studies of Phase-Transitions in GasEvaporated $\mathrm{WO}_{3}$ Microcrystals, Solid State Commun. 75 (1990) 613-616.

[55] L. Filipovic, S. Selberherr, Performance and Stress Analysis of Metal Oxide Films for CMOS-Integrated Gas Sensors, Sensors. 15 (2015) 7206-7227.

[56] M. Phillips, J. Herrera, S. Krishnan, M. Zain, J. Greenberg, R.N. Cataneo, Variation in volatile organic compounds in the breath of normal humans, J. Chromatogr. B. 729 (1999) 7588. 
[57] J.D. Fenske, S.E. Paulson, Human breath emissions of VOCs, J. Air Waste Manag. Assoc. 49 (1999) 594-598.

[58] U.C. Ghoshal, How to Interpret Hydrogen Breath Tests, J. Neurogastroenterol. Motil. 17 (2011) 312-317.

[59] E. Comini, G. Faglia, G. Sberveglieri, Solid State Gas Sensing, 1st ed., Springer, US, 2009.

[60] N. Barsan, D. Koziej, U. Weimar, Metal oxide-based gas sensor research: How to? Sens. Actuators B: Chem. 121 (2007) 18-35.

[61] A. Kolmakov, D.O. Klenov, Y. Lilach, S. Stemmer, M. Moskovits, Enhanced Gas Sensing by Individual $\mathrm{SnO}_{2}$ Nanowires and Nanobelts Functionalized with Pd Catalyst Particles, Nano Lett. 5 (2005) 667-673.

[62] K.J. Albert, N.S. Lewis, C.L. Schauer, G.A. Sotzing, S.E. Stitzel, T.P. Vaid, D.R. Walt, Cross-reactive chemical sensor arrays, Chem. Rev. 100 (2000) 2595-2626.

[63] G. Korotcenkov, Handbook of Gas Sensor Materials, in: Anonymous 1st ed., Filters in Gas Sensors, Springer;, New York, 2013, pp. 293-303.

[64] T. Kida, T. Kuroiwa, M. Yuasa, K. Shimanoe, N. Yamazoe, Study on the response and recovery properties of semiconductor gas sensors using a high-speed gas-switching system, Sens. Actuators B: Chem. 134 (2008) 928-933. 
[65] Y. Liu, Y. Lei, Pt-CeO $\mathrm{C}_{2}$ nanofibers based high-frequency impedancemetric gas sensor for selective $\mathrm{CO}$ and $\mathrm{C}_{3} \mathrm{H}_{8}$ detection in high-temperature harsh environment, Sens. Actuators B: Chem. 188 (2013) 1141-1147.

[66] M. Holmberg, F. Winquist, I. Lundström, F. Davide, C. DiNatale, A. D'Amico, Drift counteraction for an electronic nose, Sens. Actuators B: Chem. 36 (1996) 528-535.

[67] J.G. Monroy, J. González-Jiménez, J.L. Blanco, Overcoming the Slow Recovery of MOX Gas Sensors through a System Modeling Approach, Sensors (Basel, Switzerland). 12 (2012) 13664-13680.

[68] J. Gonzalez-Jimenez, J.G. Monroy, J.L. Blanco, The Multi-Chamber Electronic Nose--An Improved Olfaction Sensor for Mobile Robotics, Sensors (Basel, Switzerland). 11 (2011) 61456164.

[69] M. Zuppa, C. Distante, P. Siciliano, K.C. Persaud, Drift counteraction with multiple selforganising maps for an electronic nose, Sens. Actuators B: Chem. 98 (2004) 305-317.

[70] Z. Fan, J.G. Lu, Gate-refreshable nanowire chemical sensors, Appl. Phys. Lett. 86 (2005) 123510.

[71] C. Li, D. Zhang, X. Liu, S. Han, T. Tang, J. Han, C. Zhou, $\mathrm{In}_{2} \mathrm{O}_{3}$ nanowires as chemical sensors, Appl. Phys. Lett. 82 (2003) 1613-1615.

[72] W. Yan, M. Hu, P. Zeng, S. Ma, M. Li, Room temperature $\mathrm{NO}_{2}$-sensing properties of $\mathrm{WO}_{3}$ nanoparticles/porous silicon, Appl. Surf. Sci. 292 (2014) 551-555. 
[73] J. Zeng, M. Hu, W. Wang, H. Chen, Y. Qin, $\mathrm{NO}_{2}$-sensing properties of porous $\mathrm{WO}_{3}$ gas sensor based on anodized sputtered tungsten thin film, Sens. Actuators B: Chem. 161 (2012) $447-452$. 


\section{Figure captions}

1. Simplified model explaining the $\mathrm{NO}_{2}$ sensing phenomenon by monoclinic $\gamma-\mathrm{WO}_{3}$. (a) Band bending after ionosorption of oxygen. $\mathrm{E}_{\mathrm{C}}, \mathrm{E}_{\mathrm{F}}$ and $\mathrm{E}_{\mathrm{V}}$ denotes the energy of conduction band, Fermi level and valence band respectively. $\mathrm{qV}_{\mathrm{S}}$ and $2 \Lambda_{\text {gas }}$ denotes the band bending height and thickness respectively. (b) Structure of $\gamma-\mathrm{WO}_{3}$. (c) $\gamma-\mathrm{WO}_{3}$ thin film deposited on a gold interdigitated electrode.

2. Arrangement of the Reactive Spray Deposition Technology for direct deposition of $\mathrm{WO}_{3}$ on gold interdigitated electrodes.

3. Schematic of the gas sensing test setup.

4. (a) X-ray diffraction (b) Raman spectroscopy of $\mathrm{WO}_{3}$ film directly deposited on gold interdigitated electrodes, both pre and post $\mathrm{NO}_{2}$ test showing that there is no change in the structure of the film.

5. Microscopy images of $\mathrm{WO}_{3}$ deposited by RSDT: (a) Cross-section of the $\mathrm{WO}_{3}$ film on a $\mathrm{Si}$ substrate showing a thickness of $2.5 \mu \mathrm{m}$, (b) $\mathrm{WO}_{3}$ film deposited on gold interdigitated electrodes, (c) higher magnification view of the $\mathrm{WO}_{3}$ film on a gold line. Transmission electron microscopy (TEM) images of $\mathrm{WO}_{3}$ films deposited by RSDT: (d) $\mathrm{WO}_{3}$ primary particle size in the range 20-30 $\mathrm{nm}$. Selected area diffraction pattern (SADP) is shown in the inset (e) high resolution image of a $\mathrm{WO}_{3}$ particle showing lattice fringes corresponding to the (002) plane.

6. (a) Relation between sensor response $\left(\mathrm{R}_{\mathrm{a}}=\right.$ resistance of $\mathrm{WO}_{3}$ film in pure air, $\mathrm{R}_{\mathrm{g}}=$ resistance of $\mathrm{WO}_{3}$ film in $\mathrm{NO}_{2}$ ) and $\mathrm{NO}_{2}$ concentration at different temperatures. (b) $\mathrm{NO}_{2}$ sensing tests conducted at $0.17-5 \mathrm{ppm} \mathrm{NO}_{2}$ in the air conducted at $300^{\circ} \mathrm{C}$ and $1500 \mathrm{sccm}$ flow rate of gases. The tests shown above were conducted on the same sample. 
7. Stability tests for $\mathrm{WO}_{3}$ sensor conducted for $300 \mathrm{~h}$ at $0.5 \mathrm{ppm} \mathrm{NO}_{2}$ in the air at $300^{\circ} \mathrm{C}$.

8. $\mathrm{NO}_{2}$ response as compared to other reducing analytes. 


\section{Table caption}

1. Comparison of the $\mathrm{WO}_{3}$ based $\mathrm{NO}_{2}$ sensors prepared by different synthesis techniques. 


\begin{tabular}{|c|c|c|c|c|c|c|}
\hline Synthesis method & $\begin{array}{l}\text { Limit of } \\
\text { detection } \\
(\text { ppm })\end{array}$ & $\begin{array}{c}\text { Working } \\
\text { temperature } \\
\left({ }^{\circ} \mathrm{C}\right)\end{array}$ & $\begin{array}{c}\text { Response } \\
\text { converted to } \\
\mathbf{R}_{\mathbf{g}} / \mathbf{R}_{\mathbf{a}}\end{array}$ & $\begin{array}{c}\text { Response } \\
\text { (used formula) }\end{array}$ & $\begin{array}{l}\text { Response } \\
\text { time }\end{array}$ & Reference \\
\hline RSDT & $0.17-5$ & 300 & $\begin{array}{c}.44(0.17 \mathrm{ppm}) \\
6.58(0.5 \mathrm{ppm}) \\
7.37(1 \mathrm{ppm}) \\
8.07(5 \mathrm{ppm})\end{array}$ & $\mathbf{R}_{\mathrm{g}} / \mathbf{R}_{\mathbf{a}}$ & $7.2 \mathrm{~s}$ & This work \\
\hline $\begin{array}{l}\text { Sol-gel }\left(\mathrm{WO}_{3} \text { on }\right. \\
\text { porous silicon) }\end{array}$ & $0.05-2$ & 25 & $\begin{array}{c}\mathrm{R}_{\mathrm{a}} / \mathrm{R}_{\mathrm{g}}: \\
1.15(0.05 \mathrm{ppm}) \\
1.75(0.5 \mathrm{ppm}) \\
2.01(1 \mathrm{ppm}) \\
3.37(2 \mathrm{ppm}) \\
\end{array}$ & $\mathrm{R}_{\mathrm{a}} / \mathrm{R}_{\mathrm{g}}$ & $2 \mathrm{~min}$ & [72] \\
\hline $\begin{array}{l}\text { Sol-gel ( } \mathrm{WO}_{3} \text { on } \\
\text { alumina) }\end{array}$ & $0.05-2$ & 150 & $\begin{array}{l}1.65(0.5 \mathrm{ppm}) \\
2(1 \mathrm{ppm}) \\
2.67(2 \mathrm{ppm})\end{array}$ & $\mathrm{R}_{\mathrm{g}} / \mathrm{R}_{\mathrm{a}}$ & $2 \mathrm{~min}$ & [72] \\
\hline $\begin{array}{l}\text { DC magnetron } \\
\text { sputtering (Porous } \\
\mathrm{WO}_{3} \text { ) }\end{array}$ & $0.1-5$ & 150 & $42.2(1 \mathrm{ppm})$ & $\left(\mathrm{R}_{\mathrm{g}}-\mathrm{R}_{\mathrm{a}}\right) / \mathrm{R}_{\mathrm{a}}$ & $2 \mathrm{~min}$ & [73] \\
\hline $\begin{array}{l}\text { DC magnetron } \\
\text { sputtering (Sputtered } \\
\mathrm{WO}_{3} \text { ) }\end{array}$ & $0.1-5$ & 200 & $8.2(1 \mathrm{ppm})$ & $\left(\mathrm{R}_{\mathrm{g}}-\mathrm{R}_{\mathrm{a}}\right) / \mathrm{R}_{\mathrm{a}}$ & $2 \mathrm{~min}$ & [73] \\
\hline $\begin{array}{l}\text { Evaporation } \\
\text { condensation }\end{array}$ & $1-200$ & 250 & $2(1 \mathrm{ppm})$ & $\left(\mathrm{R}_{\mathrm{g}}-\mathrm{R}_{\mathrm{a}}\right) / \mathrm{R}_{\mathrm{a}}$ & $70 \mathrm{~min}$ & {$[13]$} \\
\hline Drop coating & $0.5-5 \mathrm{ppm}$ & 100 and 200 & $19.2(1 \mathrm{ppm})$ & $\mathrm{R}_{\mathrm{g}} / \mathrm{R}_{\mathrm{a}}$ & $15 \min$ & [32] \\
\hline
\end{tabular}




\begin{tabular}{|l|c|c|c|c|c|c|}
\hline $\begin{array}{l}\text { Glancing angle DC } \\
\text { magnetron sputtering }\end{array}$ & $0.1-2 \mathrm{ppm}$ & 250 & $4.4(0.5 \mathrm{ppm})$ & $\mathrm{R}_{\mathrm{g}} / \mathrm{R}_{\mathrm{a}}$ & $15 \mathrm{~min}$ \\
\hline $\begin{array}{l}\text { Induction-heating } \\
\text { oxidation of tungsten }\end{array}$ & $1-8 \mathrm{ppm}$ & 110 & $5.5(1 \mathrm{ppm})$ & $\mathrm{R}_{\mathrm{g}} / \mathrm{R}_{\mathrm{a}}$ & $10 \mathrm{~min}$ \\
\hline PECVD & $10-100 \mathrm{ppm}$ & 200 & $45(10 \mathrm{ppm})$ & $\mathrm{V}_{\mathrm{g}} / \mathrm{V}_{\mathrm{a}}\left(\mathrm{same} a \mathrm{R}_{\mathrm{g}} / \mathrm{R}_{\mathrm{a}}\right)$ & $50 \mathrm{~s}$ \\
\hline Spray pyrolysis & $10-100 \mathrm{ppm}$ & 200 & $1.5(20 \mathrm{ppm})$ & {$\left[\left(\mathrm{R}_{\mathrm{g}}-\mathrm{R}_{\mathrm{a}}\right) / \mathrm{R}_{\mathrm{a}}\right]^{*} 100$} & $3 \mathrm{~s}]$ \\
\hline
\end{tabular}




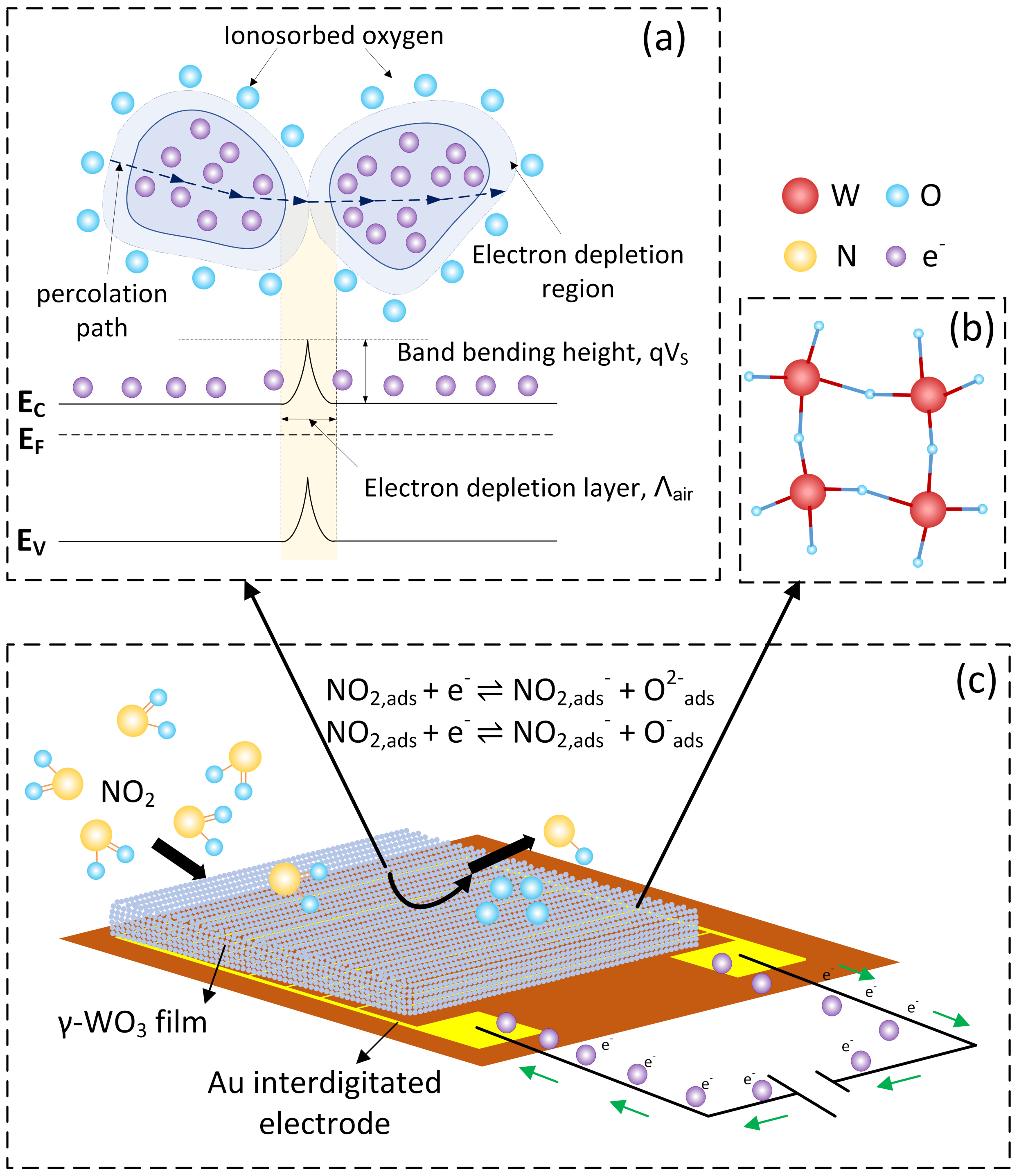




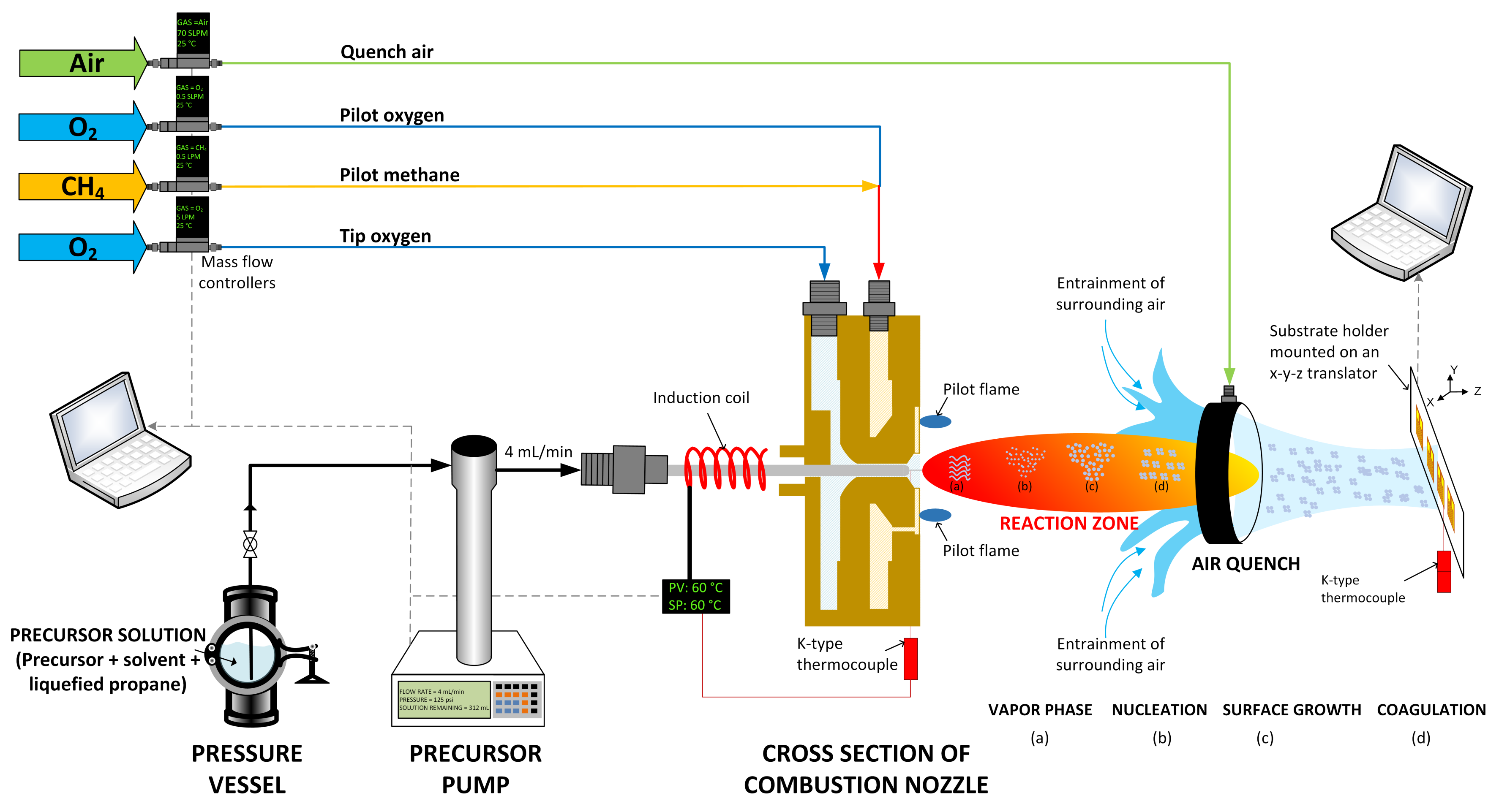




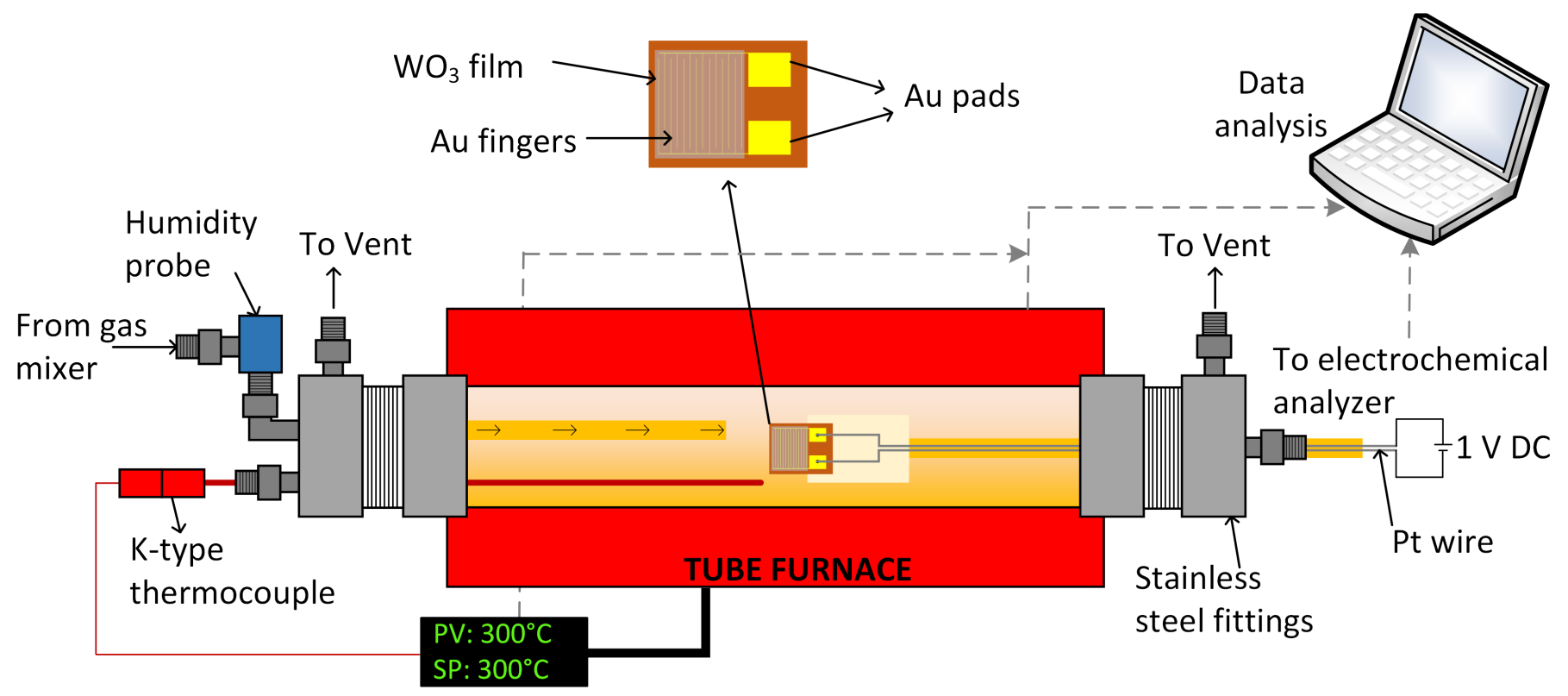



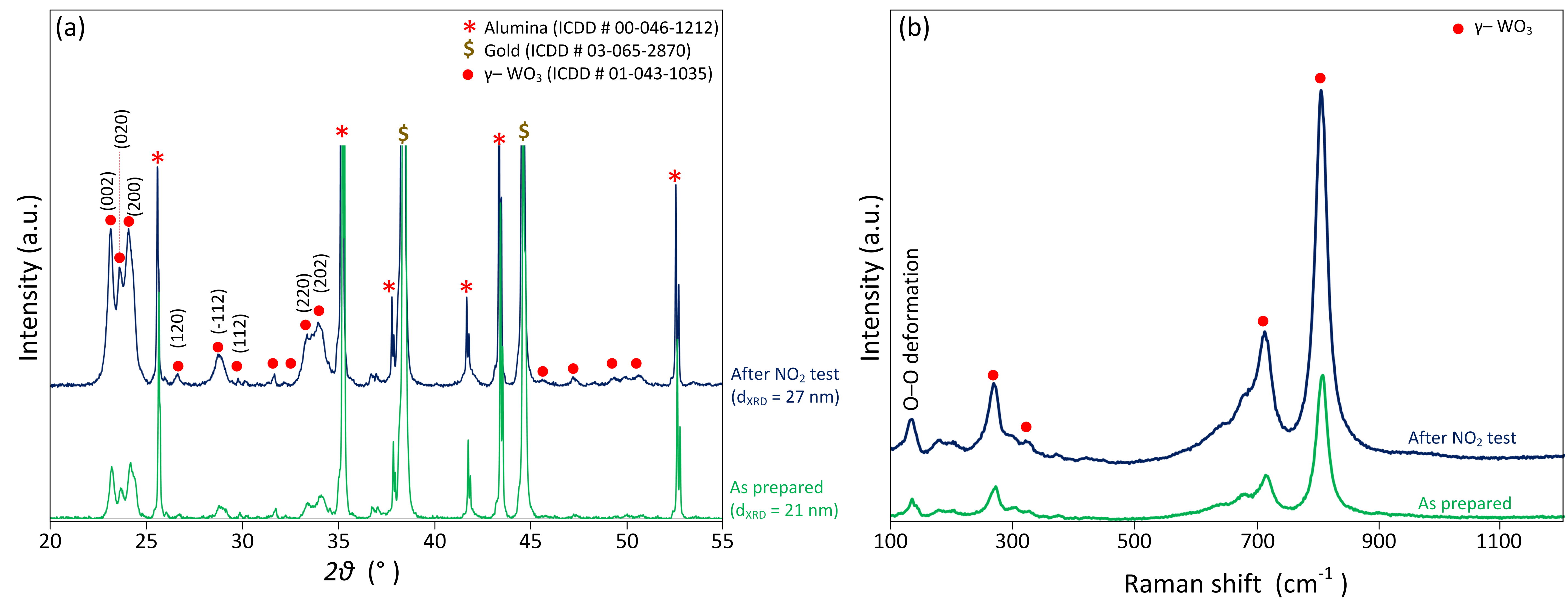

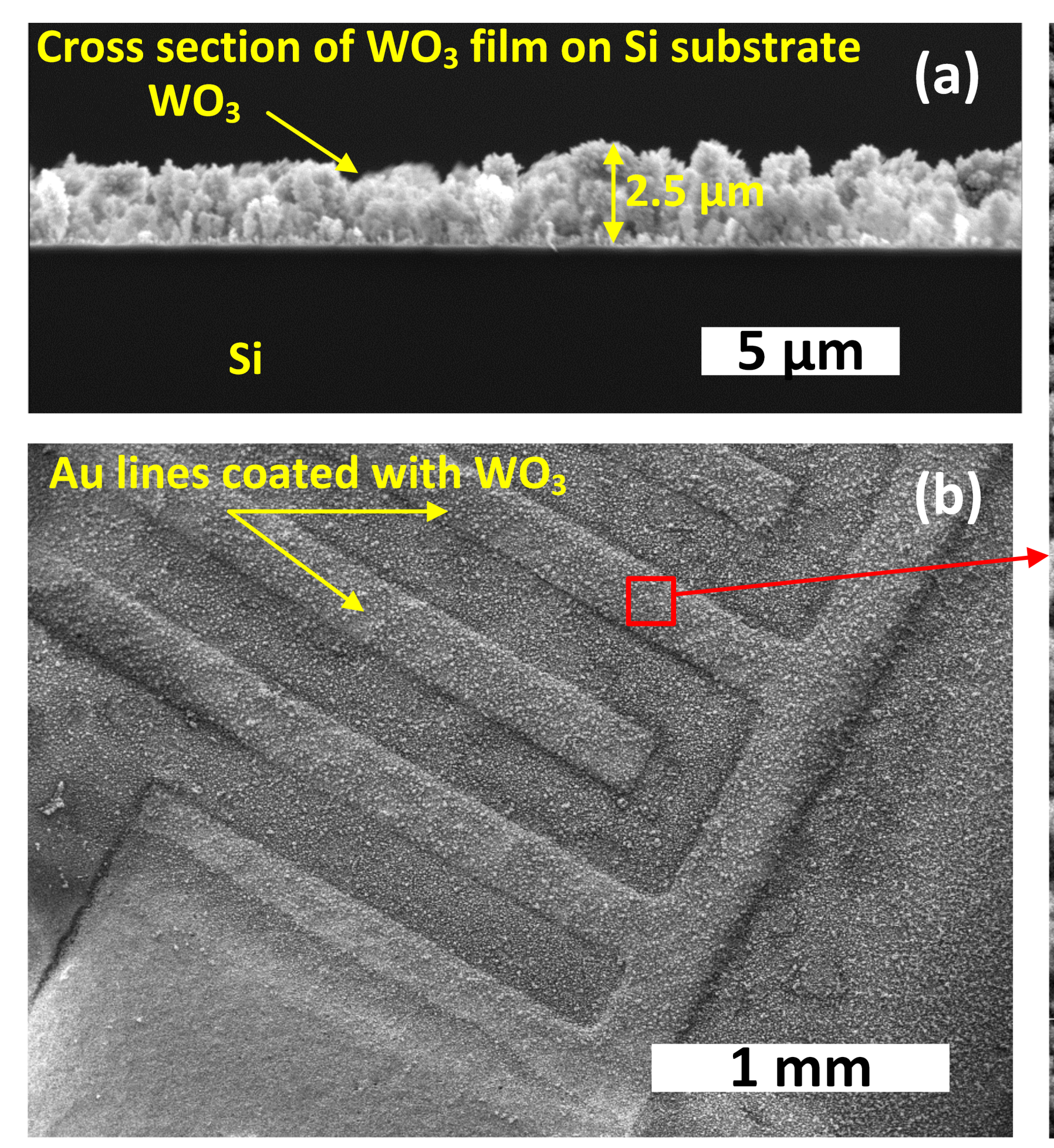

(b)
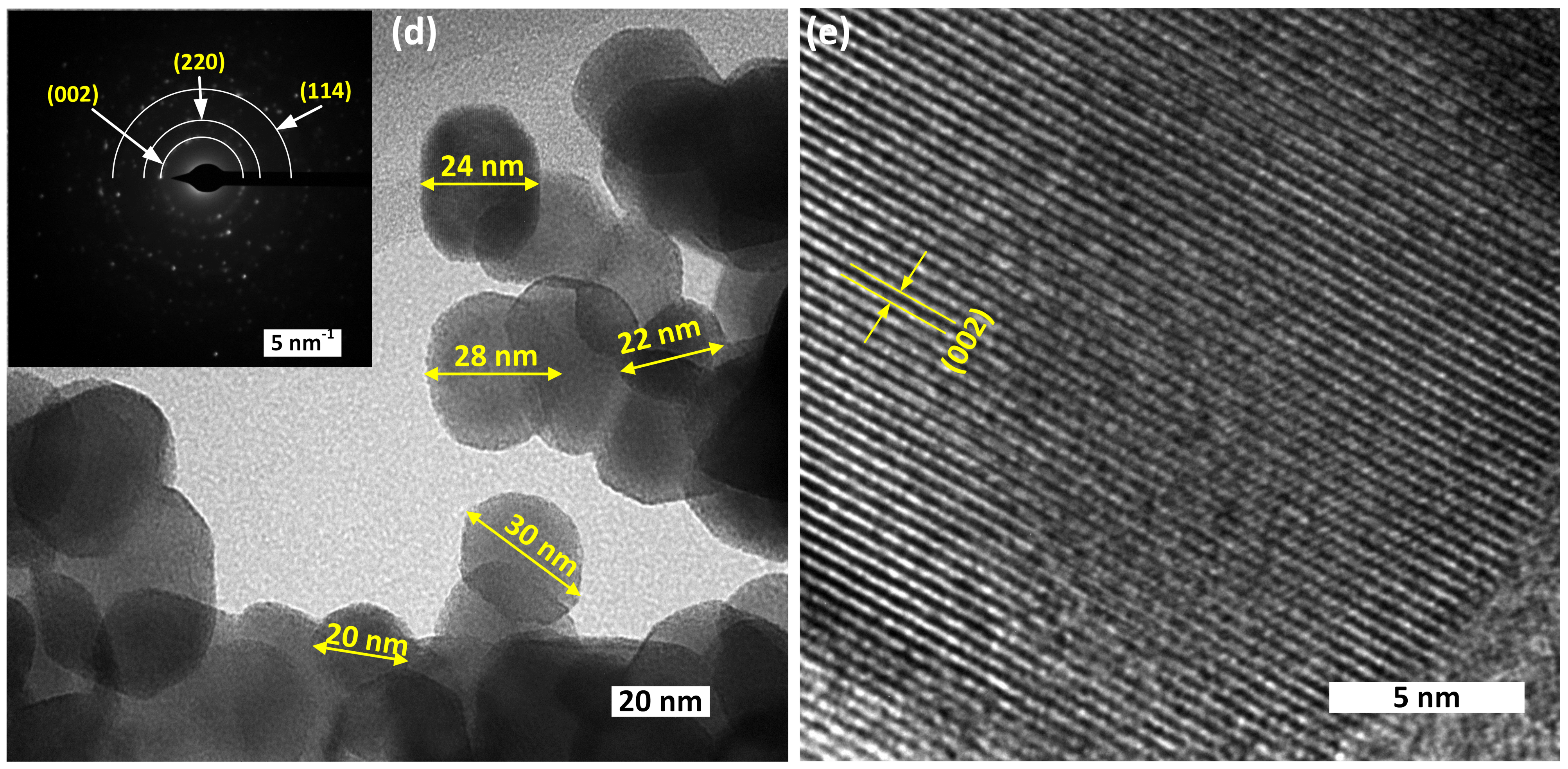

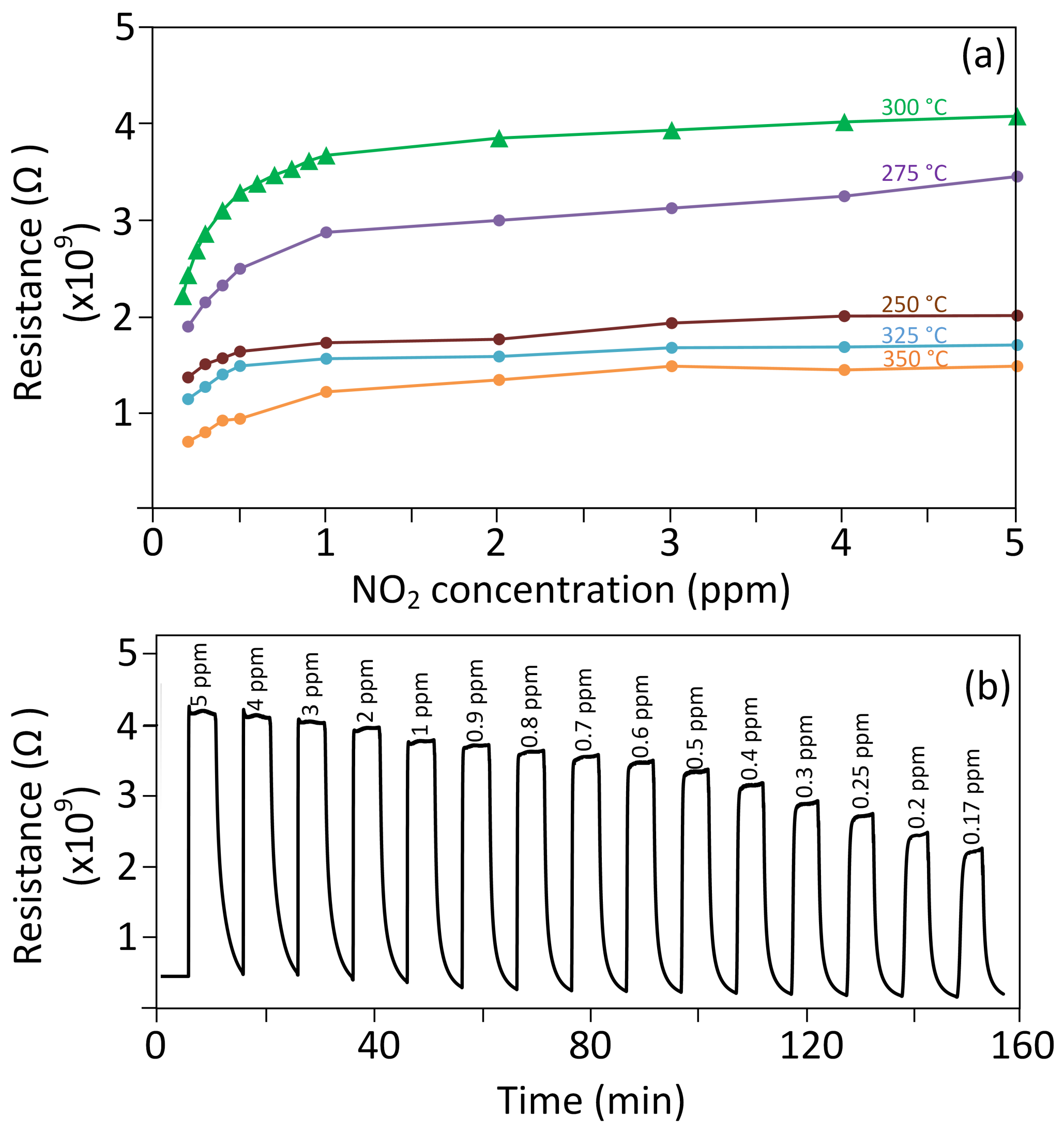


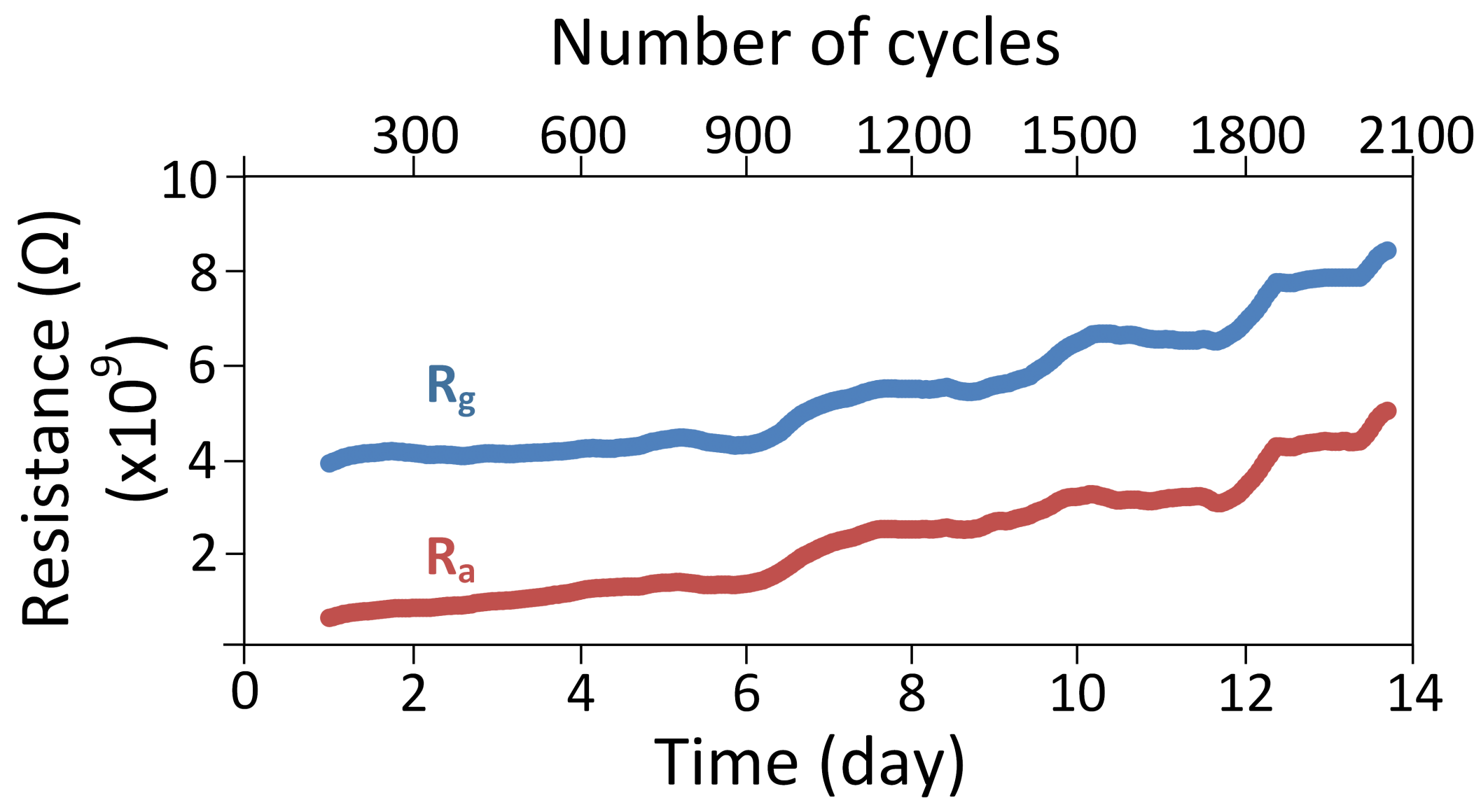



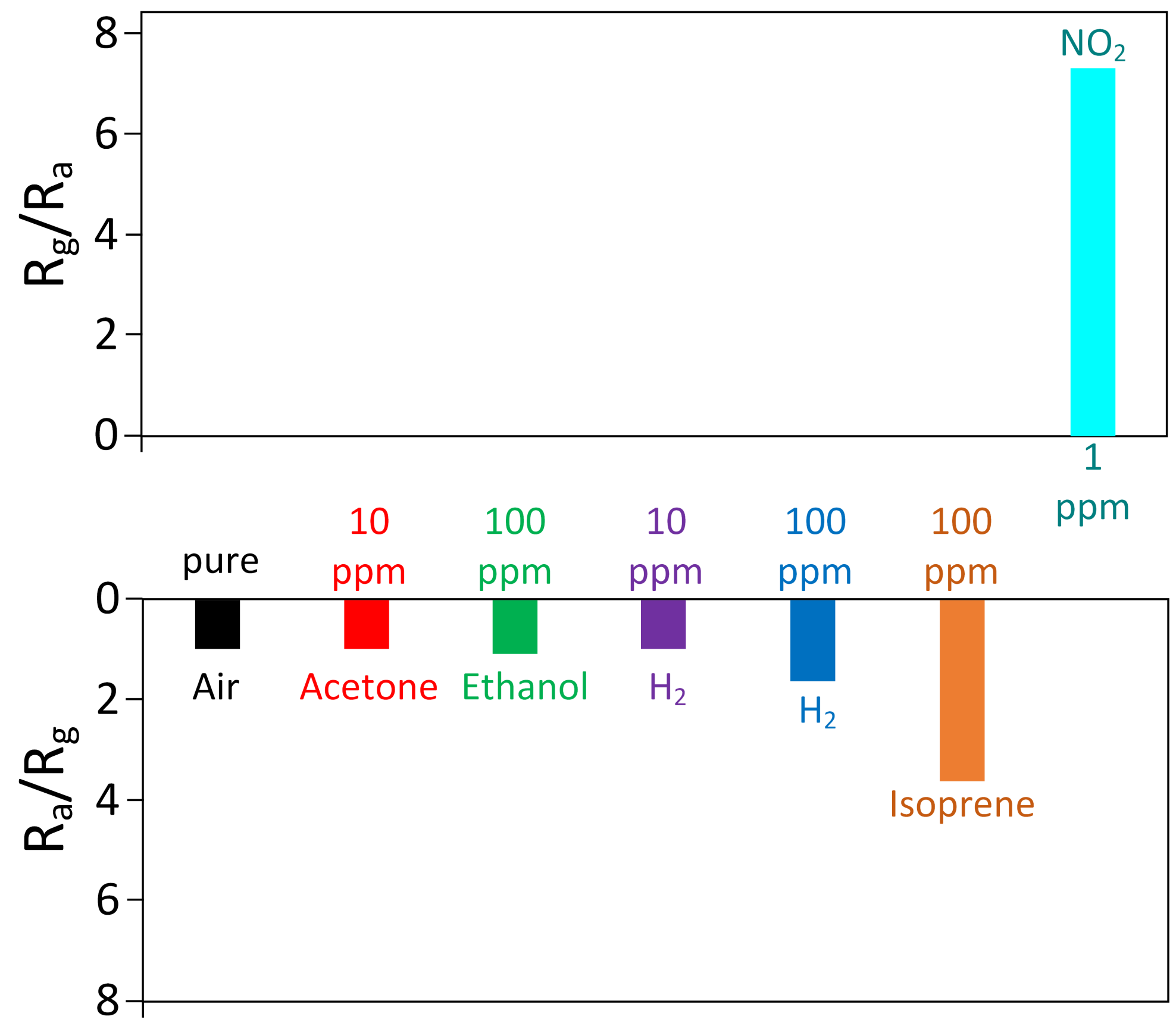
Rishabh Jain is a Process Technology Development Engineer at Intel Corporation in Hillsboro, Oregon, USA. Dr. Jain obtained his Ph.D. in Materials Science and Engineering from University of Connecticut (UConn) in 2015 where he worked at the Center for Clean Energy Engineering as a graduate research assistant. His area of expertise is on the flame combustion synthesis of nanomaterial thin films for catalysts and gas sensors. In addition to that, Dr. Jain also excels in the electron microscopy and microstructural characterization of nanomaterials.

Yu Lei is a Castleman associate professor of Chemical and Biomolecular Engineering at the University of Connecticut, USA. Dr. Lei obtained his Ph.D. degree in 2004 at the University of California-Riverside in Chemical and Environmental Engineering. His current research combines biotechnology, nanotechnology, and sensing technology, especially as applied to the development of explosives sensors, gas sensors, electrochemical sensors, and biosensors.

Radenka Maric is a named Professor in Sustainable Energy in the University of Connecticut's department of Chemical \& Biomolecular Engineering and department of Materials Science and Engineering. Dr. Maric has research interests in the areas of synthesis of nanomaterials, catalysis, kinetics, electrochemical cell design and architecture, new analytical and diagnostic techniques, fuel cell and battery systems, alternative electrochemical fuels and reactant modification, hydrogen production and storage, and sensor technology. Before joining UConn (2010), she was a group leader and program manager at the National Research Council (NRC) of Canada's Institute for Fuel Cell Innovation. Dr. Maric was the first woman to receive a Ph.D. in engineering from Kyoto University, Japan. She is an elected member of the Connecticut Academy of Science and Engineering. 